University of Nebraska - Lincoln

DigitalCommons@University of Nebraska - Lincoln

Publications from USDA-ARS / UNL Faculty

U.S. Department of Agriculture: Agricultural

Research Service, Lincoln, Nebraska

2013

\title{
Land cover controls on summer discharge and runoff solution chemistry of semi-arid urban catchments
}

\author{
Erika L. Gallo \\ University of Arizona, elgallo@email.arizona.edu \\ Paul D. Brooks \\ University of Arizona, paul.brooks@utah.edu \\ Kathleen A. Lohse \\ University of Arizona, klohse@isu.edu \\ Jean E.T. McLain \\ University of Arizona, jmclain@cals.arizona.edu
}

Follow this and additional works at: https://digitalcommons.unl.edu/usdaarsfacpub

Gallo, Erika L.; Brooks, Paul D.; Lohse, Kathleen A.; and McLain, Jean E.T., "Land cover controls on summer discharge and runoff solution chemistry of semi-arid urban catchments" (2013). Publications from USDAARS / UNL Faculty. 1151.

https://digitalcommons.unl.edu/usdaarsfacpub/1151

This Article is brought to you for free and open access by the U.S. Department of Agriculture: Agricultural Research Service, Lincoln, Nebraska at DigitalCommons@University of Nebraska - Lincoln. It has been accepted for inclusion in Publications from USDA-ARS / UNL Faculty by an authorized administrator of DigitalCommons@University of Nebraska - Lincoln. 


\title{
Land cover controls on summer discharge and runoff solution chemistry of semi-arid urban catchments
}

\author{
Erika L. Gallo ${ }^{\mathrm{a}, *}$, Paul D. Brooks ${ }^{\mathrm{a}}$, Kathleen A. Lohse ${ }^{\mathrm{b}, 1}$, Jean E.T. McLain ${ }^{\mathrm{c}, \mathrm{d}}$ \\ ${ }^{a}$ Department of Hydrology and Water Resources, University of Arizona, Tucson, AZ 85721, United States \\ ${ }^{\mathrm{b}}$ School of Natural Resources and the Environment, University of Arizona, Tucson, AZ 85721, United States \\ c USDA-ARS, US Arid-Land Agricultural Research Center, Maricopa, AZ 85138, United States \\ ${ }^{\mathrm{d}}$ Water Resources Research Center, University of Arizona, Tucson, AZ 85719, United States
}

\section{A R T I C L E I N F O}

\section{Article history:}

Available online 3 December 2012

\section{Keywords:}

Urban

Runoff

Water quality

Land use

Semi-arid

\begin{abstract}
S U M M A R Y
Recharge of urban runoff to groundwater as a stormwater management practice has gained importance in semi-arid regions where water resources are scarce and urban centers are growing. Despite this trend, the importance of land cover in controlling semi-arid catchment runoff quantity and quality remains unclear. Here we address the question: How do land cover characteristics control the amount and quality of storm runoff in semi-arid urban catchments? We monitored summertime runoff quantity and quality from five catchments dominated by distinct urban land uses: low, medium, and high density residential, mixed use, and commercial. Increasing urban land cover increased runoff duration and the likelihood that a rainfall event would result in runoff, but did not increase the time to peak discharge of episodic runoff. The effect of urban land cover on hydrologic responses was tightly coupled to the magnitude of rainfall. At distinct rainfall thresholds, roads, percent impervious cover and the stormwater drainage network controlled runoff frequency, runoff depth and runoff ratios. Contrary to initial expectations, runoff quality did not vary in repose to impervious cover or land use. We identified four major mechanisms controlling runoff quality: (1) variable solute sourcing due to land use heterogeneity and above ground catchment connectivity; (2) the spatial extent of pervious and biogeochemically active areas; (3) the efficiency of overland flow and runoff mobilization; and (4) solute flushing and dilution. Our study highlights the importance of the stormwater drainage systems characteristics in controlling urban runoff quantity and quality; and suggests that enhanced wetting and in-stream processes may control solute sourcing and retention. Finally, we suggest that the characteristics of the stormwater drainage system should be integrated into stormwater management approaches.
\end{abstract}

(c) 2012 Elsevier B.V. All rights reserved.

\section{Introduction}

Groundwater recharge of urban runoff has gained importance as a potential strategy to offset municipal water demands in arid and semi-arid regions (Chralowicz et al., 2001; Crowley et al., 2005; Decook and Foster, 1984). In these regions, water resources are scarce, and population growth and urban expansion are expected to continue to increase (Berling-Wolff and Wu, 2004; Norman et al., 2009). Moreover, projected climate changes are likely to increase the uncertainty of future water resources with

\footnotetext{
* Corresponding author. Present address: Department of Biological Sciences, Idaho State University, Pocatello, ID 83209, United States. Tel.: +1 (520) 390 5770; fax: +1 (520) 6211422 .

E-mail addresses: elgallo@email.arizona.edu (E.L. Gallo), brooks@hwr.arizona. edu (P.D. Brooks), klohse@isu.edu (K.A. Lohse), jmclain@cals.arizona.edu (J.E.T. McLain).

1 Present address: Department of Biological Sciences, Idaho State University, Pocatello, ID 83209, United States.
}

higher temperatures and more extreme patterns in rainfall (Gelt et al., 1999; Serrat-Capdevila et al., 2007); thus, municipalities are seeking alternatives to enhance groundwater recharge and encourage water resources conservation.

Recharge in arid and semi-arid regions typically occurs along mountain fronts and via infiltration in ephemeral stream channels during the summer months, when high intensity rainfall generates most of the annual runoff (Gochis et al., 2006; Goodrich et al., 1997; Resnick et al., 1983). Because runoff quantity increases with increasing rainfall magnitude and percent impervious cover in some semi-arid catchments (Gallo et al., 2012), urbanization may enhance runoff recharge in ephemeral waterways and augment localized water resources. Indeed, recent work using groundwater age tracers by Carlson et al. (2011) indicates recharge of new waters in ephemeral channels and increases in groundwater nitrate in an urban semi-arid basin. Questions remain about the sources of these new waters, the quality of urban runoff for potential recharge, and how land cover controls urban hydrology and 
hydrochemistry, information that is critical for management of groundwater quality.

Numerous studies across a wide range of geographic locations and climates show that urbanization can alter catchment hydrologic responses and negatively impact surface and downstream waters (for example: Athayde et al., 1983; EPA, 1997; Maestre and Pitt, 2006; Shuster et al., 2005; Smullen et al., 1999; Walsh et al., 2005a; Wenger et al., 2009; Zampella et al., 2007). Early urban runoff monitoring efforts such as Nation Wide Urban Runoff Program (NURP, Smullen et al., 1999), the National Water Quality Assessment Program (NAWQA, Brown et al., 2009) and the National Stormwater Quality database (NSQD, Maestre and Pitt, 2006; Pitt et al., 2008) aimed to identify urban runoff responses from distinct urban land uses. However, the data showed mixed responses to land use, indicating more complex controls on urban runoff responses. Some conceptual models suggest that both, urban runoff quantity and quality, are primarily controlled by percent impervious cover (Arnold and Gibbons, 1996; Paul and Meyer, 2001; Schueler, 1994), while others indicate that urban runoff quality and quantity are largely controlled by the extent of catchment connectivity and the characteristics of the stormwater drainage system (Carle et al., 2005; Hatt et al., 2004; Meierdiercks et al., 2010; Ogden et al., 2011; Walsh et al., 2009). However, few studies have specifically addressed how urbanization alters runoff responses in semi-arid regions (for example: Asaf et al., 2004; Ishaq and Alassar, 1999; Jiries et al., 2001; Lewis and Grimm, 2007) where runoff and subsequent streamflow occur only in response to rainfall. A recent study by Gallo et al. (2012), for example, showed that short term (hours) partitioning of rainfall controls the temporal patterns of urban hydrologic responses in semi-arid study catchments in Tucson, AZ. In contrast, the temporal patterns in runoff quality were controlled by the magnitude, frequency and timing of rainfall. However, the role of land cover and its configuration in controlling runoff hydrology and hydrochemistry remains unclear.

In this study, we address the question: How do land cover characteristics control storm runoff quantity and quality in semi-arid urban catchments? We monitored runoff quantity and quality in five small $\left(<4.7 \mathrm{~km}^{2}\right)$ urban catchments in Tucson, Arizona during the summer rainfall seasons of 2007 and 2008 . We identified instances of collinearity among land cover variables, and quantified the effect of summertime rainfall and land cover characteristics on urban runoff responses. We expected runoff quantity to increase and runoff quality to decrease with increasing urbanization, specifically in response to impervious cover and the characteristics of the stormwater drainage system. We show that the effects of land cover on some aspects of urban hydrology vary with the magnitude of rainfall; that runoff quality does not vary directly with urban land cover; and we highlight mechanisms controlling runoff quality.

\section{Study region and study period overview}

The study catchments are located in the Tucson Metropolitan area in southern Arizona, USA within an alluvial basin bounded by the Tucson, Santa Catalina and Rincon mountains to the west, north and east, respectively (Hoffmann et al., 2007). The Tucson Mountains are primarily Late Cretaceous to Early Tertiary andesite and dacite, and alluvium from this range is constrained to the west of the Santa Cruz River and does not underlay our study catchments (Ludington et al., 2007). The Catalina and Rincon Mountains are primarily composed of Late Cretaceous to Early Tertiary granite and pegmatite, and to a lesser extent early Proterozoic to Tertiary gneiss and mylonite. Late Pliocene to early Pleistocene alluvial fans comprise the Catalina and Rincon Mountain foothills, and quaternary granitic alluvium derived from these two ranges makes up the basin fill east of the Santa Cruz River (Ludington et al., 2007).
The major Santa Cruz River tributaries, the Canada del Oro, Rillito Creek, Pantano Wash and Tanque Verde Creek are ephemeral waterways that flow to the northwest of the basin (Wilson et al., 1998), and have been identified as areas of focused groundwater recharge (Eastoe et al., 2004).

The regional climate is semi-arid; mean annual precipitation is approximately $310 \mathrm{~mm}$, potential evapotranspiration exceeds $1960 \mathrm{~mm} \mathrm{yr}^{-1}$ (Gelt et al., 1999; Wilson et al., 1998), and evaporation can exceed $250 \mathrm{~mm} \mathrm{yr}^{-1}$ (Unland et al., 1996). The Tucson Metropolitan Area is located within the Sonoran Desert Ecoregion, the wettest North American Desert (Arizona Game and Fish Department, 2006). Precipitation in the Sonoran Desert is bimodally distributed with approximately $48 \%$ of rainfall occurring during the summer months as thunderstorms (i.e. the North American Monsoon, Gelt et al., 1999) that follow an extended period (2-3 months) of hot and dry conditions. Atmospheric convection generates monsoonal rainfall (Gelt et al., 1999; Hoffmann et al., 2007), which is characterized by its short duration, high intensity and high spatial heterogeneity (Garcia et al., 2008; Morin et al., 2006; Syed et al., 2003). Data from Morin et al. (2006) indicate that monsoonal thunderstorms can be spatially isolated to a radius as small as $2 \mathrm{~km}$. In contrast, winter precipitation events are longer in duration, lower in intensity, spatially widespread, and evenly distributed. Winter rainfall accounts for most mountain front recharge in non-urban settings (Coes and Pool, 2007; Eastoe et al., 2004); however, a significant proportion of recharge occurs via stream channel infiltration of runoff generated in response to monsoonal rainfall (Baillie et al., 2007; Goodrich et al., 2004). Therefore, urban rainfall-runoff responses may significantly impact ephemeral channel recharge. This study was conducted between June 15th and September 30th of 2007 and 2008, the official span of the summer monsoon (Guido, 2008), when infiltration excess overland flow of monsoonal rainfall generates most of the annual runoff (Gochis et al., 2006; Goodrich et al., 1997; Stone et al., 2008).

\section{Methods}

\subsection{Catchment characterization}

We monitored urban runoff responses from 5 hydrologically isolated catchments, each dominated by a specific type of urban land use: (1) low density residential (LD), (2) medium density residential (MD), (3) high density residential (HD), (4) mixed land use (MX), and (5) commercial land use (CM, Fig. 1). The catchments were delineated in ArcMap 9.0 using the stormwater drainage system, which does not share any infrastructure with the sewer system, and using $0.65 \mathrm{~m}$ elevation data provided by the City of Tucson's Office of Conservation and Sustainable Development (Tucson OCSD) and the Pima County Department of Transportation (http://www.dot.co.pima.az.us/gis/maps/). The percent low, medium and high density residential housing, the percent commercial development (commercial + roads), and the percent open space (parks + undeveloped land + agricultural land) for each catchment were determined from December 2006 parcel-level hydrologic land use data provided by Tucson OCSD as follows:

$f a_{L C X}=100 \cdot \frac{a_{L C X}}{a_{c}}$

where $f a_{L C x}$ is the catchment proportion of land cover $x, a_{c}$ is the catchment size or area in $\mathrm{km}^{2}$ and $a_{L C x}$ is the area in $\mathrm{km}^{2}$ of land cover $x$. Areas were calculated using the "Area Calculation by Gauss" method in ArcMap 9.0. Percent impervious cover (IC) within the catchments was determined as follows:

$I C=\sum_{x=i}^{n} f a_{L C x} \cdot f I C_{L C X}$ 

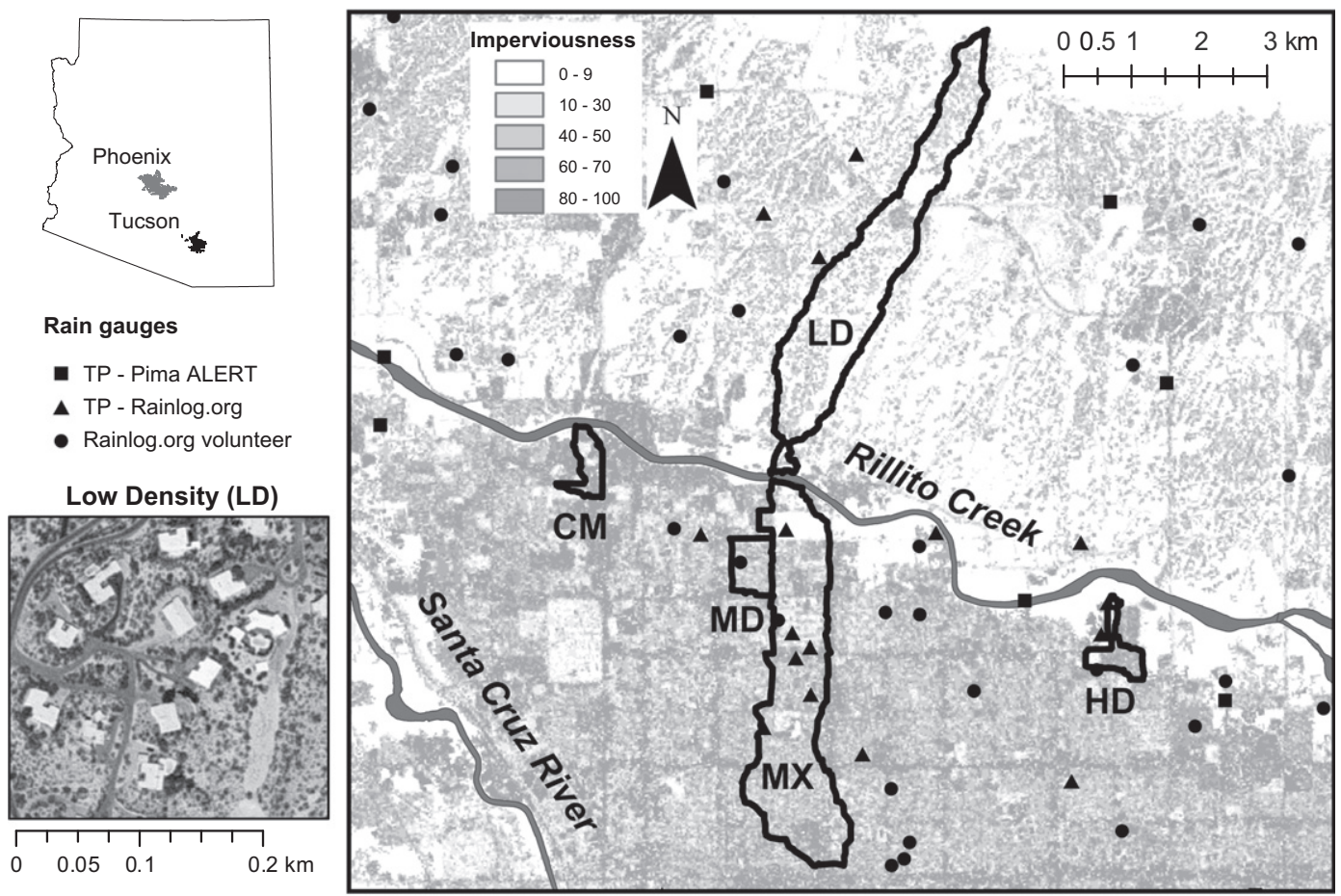

Medium Density (MD)
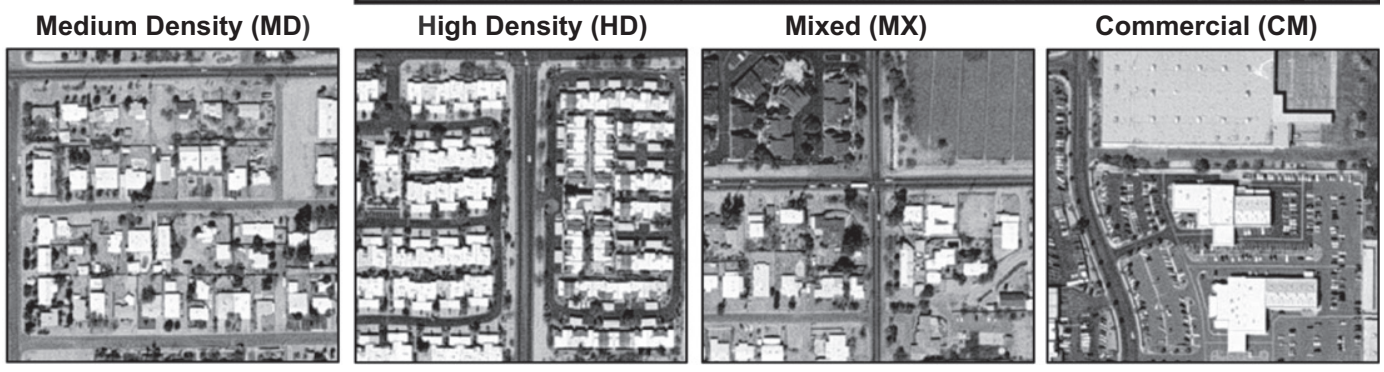

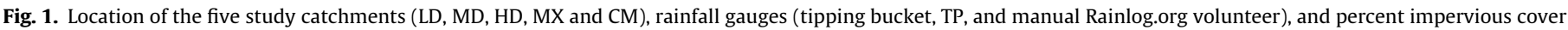
within the Tucson Basin in south-eastern Arizona. Small inset figures are land cover orthoimagery examples of each catchment.

where $f I C_{L C X}$ is the fraction of percent impervious cover of land cover $x$ obtained from Tucson OCSD. The "stormwater drainage system" is comprised of natural and engineered pervious and impervious features that, according to Tucson OCSD and the Tucson Department of Transportation are meant to convey storm runoff. Given that there are no stormwater retention ponds or basins in any of our study catchments, "pervious stream channels" comprise the pervious features of the stormwater drainage system. The impervious features of the stormwater drainage system or "impervious channels" henceforth, include subsurface pipes, culverts, above ground concrete lined channels and catch basins. The densities of roads, the stormwater drainage system (pervious + impervious channels) and pervious and impervious channels were determined by dividing the total length of each by the catchment area. Finally, we used data from the U.S. Geological Survey (Ludington et al., 2007) and the SSRUGO database (Natural Resources Conservation Service, 2008) to identify the underlying geologic material and soil types at our study sites.

Our study sites are not single land cover catchments. To characterize land cover heterogeneity within each catchment we used the Landscape Evenness Index $(L E)$, which is analogous to the Shannon Evenness Index (Shannon diversity:maximum diversity) and describes the relative abundance of species in a community assemblage (Pielou, 1966). Similarly, $L E$ describes the relative abundance of land cover types with respect to the total number of land covers (Weng, 2007; Zhang and Wang, 2006), and is calculated as follows:
$L E=\frac{-\sum_{i=1}^{n} p_{i} \ln p_{i}}{\ln n}$

where $n$ is the total number of land covers, and $p_{i}$ is the proportion of land cover $i$. Values close to 1 indicate an even distribution of land covers (more heterogeneous landscape); values close to 0 indicate a skew towards one dominant land cover (more homogenous landscape, Weng, 2007).

\subsection{Monsoonal rainfall and runoff}

Convective summertime monsoonal rainfall in the semi-arid Southwest is spatially and temporally heterogeneous (Comrie and Broyles, 2002; Gochis et al., 2006; Goodrich et al., 1997; Morin et al., 2003, 2006). Extensive rainfall monitoring in the Southwest shows that the spatial distribution of monsoonal rainfall is more accurately characterized when a high spatial density of observations is available (Goodrich et al., 2008; Morin et al., 2003). In addition, rainfall intensities from a single tipping bucket rain gauge may not accurately represent catchment wide rainfall intensities (Morin et al., 2003). Therefore we used spatially distributed precipitation point data from Rainlog.org and from the Pima County Regional Flood Control District Automated Local Evaluation in Real Time System (ALERT, http://www.rfcd.pima.gov/wrd/alertsys/index.htm) to characterize monsoonal rainfall (Fig. 1). 
At a minimum, three rain gauges were located within $2 \mathrm{~km}$ of the outlet of each catchment, and the maximum distance between a point in the catchment and the nearest rain gauge was less than $2.5 \mathrm{~km}$. We set a threshold of a maximum of $30 \mathrm{~min}$ between consecutive tipping bucket rainfall gauge tips to identify individual rainfall events. We used point rainfall depth values and the inverse distance weighted method with a power of 3 as outlined by Garcia et al. (2008) in ArcMap 9.0 to calculate the depth of precipitation in $\mathrm{mm}\left(P_{\text {depth }}\right)$ for each rainfall event during the study period at each catchment. We calculated spatially and temporally averaged rainfall intensity by dividing $P_{\text {depth }}$ by the duration of rainfall obtained from Rainlog.org and ALERT tipping bucket rain gauges. Rainfall frequency at each catchment was calculated by dividing the number of monsoonal rainfall events by the number of days between the first and last observed monsoonal rainfall event.

Hydrologic responses were characterized by monitoring stream stage at the outlet of each catchment in 1-min time steps using pressure transducers (Submerged Flow Module 720, Teledyne ISCO, Lincoln, Nebraska, accuracy $\pm 0.3 \mathrm{~cm}$ ). The rapid rise in stage height in response to rainfall and subsequent flash flood conditions, and the nature of urban debris that accumulates in ephemeral waterways between runoff events presented undue risk in generating stage-velocity rating curves for discharge calculations. Therefore we used Manning's equation to calculate instantaneous discharge $\left(Q_{t}, \mathrm{~L} \mathrm{~s}^{-1}\right)$ :

$Q_{t}=A \frac{1000}{n} R_{h}^{2 / 3} s^{1 / 2}$

where $A$ is the cross sectional area of flow within the channel in meters, $n$ is the channel roughness coefficient, $R_{h}$ is the hydraulic radius in $\mathrm{m}^{2}$ and $s$ is the energy slope. We assumed that the energy slope was approximately equal to the bed slope. Due to data losses during download, we present hydrologic response data for 3 of our 5 study catchments for 2007, and all sites for 2008. Based on the characteristics of the stream channel substrate we selected $n$ values of 0.02 for $\mathrm{LD}$ and MX, 0.024 for MD and HD, and 0.013 for CM (ASCE, 1996). We calculated the event runoff depth in $\mathrm{mm}$ by summing $Q_{t}$ over the duration of the runoff event, multiplying by the time step of our observations (60 s) and dividing by the area of the catchment. The runoff ratio as a percent was calculated by dividing runoff depth by $P_{\text {depth }}$ and multiplying by 100 . Runoff duration in hours was calculated as the difference between the time stamps at the end and onset of runoff. Time to peak discharge in hours was calculated as the difference between the time stamp of the event's highest, or peak, $Q_{t}$ and the onset of runoff.

\subsection{Runoff sample collection and analyses}

We collected discrete runoff samples using automatic water samplers (ISCO 6712, Teledyne Technologies, Lincoln, Nebraska) installed at the outlet of each catchment. Samples were collected in acid washed and combusted $1 \mathrm{~L}$ glassware and compared to field blanks. Stormwater collections were triggered when stage height exceeded $1 \mathrm{~cm}$. Historical urban runoff quality data for catchments of the Tucson Basin (Resnick et al., 1983) and runoff quality samples collected over a period of $9 \mathrm{~h}$ for a runoff event in the Tucson Basin (Gallo, unpublished data) indicate that runoff chemistry is largely invariable during the tail of flow recession (after $4 \mathrm{~h}$ ). Based on this information and space limitations inside the chamber of the automatic water sampler, we collected one discrete runoff sample every $20 \mathrm{~min}$ for a maximum of $4 \mathrm{~h}$. We checked for runoff collections after every rainfall event. Runoff samples were placed in dark chilled coolers $\left(\sim 4^{\circ} \mathrm{C}\right)$ and immediately taken to the University of Arizona for processing.

Sample aliquots were immediately poured off into sterile containers for fecal indicator bacteria (Escherichia coli) analyses and immediately shipped to the USDA ARS Maricopa Agricultural Center. Total E. coli analyses followed the US EPA method 1604 membrane filter technique (EPA, 2002). All runoff samples were processed within $24 \mathrm{~h}$ of collection. We used pre-combusted $0.7 \mu \mathrm{m}$ glass fiber filters (Whatman $\mathrm{GF} / \mathrm{F}$ ) to filter aliquots for nutrient analysis. Dissolved organic carbon (DOC) and total dissolved nitrogen (TDN) concentrations were determined using a Schimatzu TOC Analyzer with TN module (Shimadzu, Columbia Maryland, detection limit (DL) $=0.05$ and $0.1 \mathrm{mg} \mathrm{L}^{-1}$, respectivley). Analysis of ammonium-N $\left(\mathrm{NH}_{4}\right)$ and orthophosphate-P (SRP) were performed on a SmartChem Discrete Analyzer (Westco Scientific, Brookfield, CT, DL $=0.002$ and $0.001 \mathrm{mg} \mathrm{L}^{-1}$, respectively). Aliquots for anion, cation and metal analyses were filtered through $0.45 \mu \mathrm{m}$ membrane filters (Millipore MF). Anion [chloride $(\mathrm{Cl})$, nitrate-N $\left(\mathrm{NO}_{3}\right)$, nitrite- $\mathrm{N}\left(\mathrm{NO}_{2}\right)$ and sulfate-S $\left.\left(\mathrm{SO}_{4}\right)\right]$ analyses were performed in a Dionex Ion Chromatograph ICS-3000 (DIONEX, San Jose, $\mathrm{CA}, \mathrm{DL}=0.05 \mathrm{mg} \mathrm{L}^{-1}$ ). Aliquots for base cations [calcium $(\mathrm{Ca})$, sodium $(\mathrm{Na})$, magnesium $(\mathrm{Mg})$, potassium $(\mathrm{K})]$ and metals [lead $(\mathrm{Pb})$, zinc $(\mathrm{Zn})$, iron $(\mathrm{Fe})$, copper $(\mathrm{Cu})$, cobalt $(\mathrm{Co})$, nickel $(\mathrm{Ni})$, aluminum $(\mathrm{Al})$, manganese $(\mathrm{Mn})$, vanadium $(\mathrm{V})$, cadmium (Cd), arsenic (As) and mercury (Hg)] were preserved with nitric acid to approximately $1 \%$ and $\mathrm{pH}$ range $2-3$. Cation and metal analyses were performed on an inductively coupled plasma mass spectrometer (Elan DRC-II ICP-MS, DL $=0.001 \mu \mathrm{g} \mathrm{L}^{-1}$ ).

\subsection{Statistical analyses}

Statistical analyses were preformed in JMP 8.0.2 software (SAS System, 2007). We used pairwise correlations to identify collinearity among land cover characteristics (Lehman et al., 2005; Rosner, 1995). We used $t$-tests to determine if the characteristics of rainfall varied significantly $(p<0.05)$ between the 2007 and 2008 summer monsoon. We compared rainfall frequency, $P_{\text {depth }}$, runoff depth, runoff ratio, time to peak discharge, runoff duration and discrete solute concentrations (solute concentrations henceforth) across sites using Tukey-Kramer means test (Hayter, 1984; Sall et al., 2007). If necessary, data were log transformed to normalize the data distribution and to meet assumptions of homogeneity of variance. To identify how hydrologic responses varied with land cover and rainfall, we regressed runoff depth, runoff ratio, time to peak discharge and runoff duration against catchment size, percent impervious cover, percent low, medium and high density residential housing, percent commercial and open land cover, $L E$, slope, the density of roads, the stormwater drainage system, pervious and impervious channels, and $P_{\text {depth }}$. Because we are interested in the direction of significant $(p<0.05)$ relationships between two variables (positive or negative) we report the correlation coefficient.

To identify response thresholds and potential rainfall and land cover controls on runoff presence and absence, runoff depth, runoff ratio, time to peak discharge and runoff duration across sites, we developed decision trees using recursive partitioning and stepwise multiple linear regression. Recursive partitioning, or classification and regression tree analysis is a statistical method that splits, or partitions, data into smaller groups (nodes) of increasingly homogenous variance to which simpler regression models can be applied (Strobl et al., 2009; Zhang, 2004). Because we were interested in maximizing the node variance explained by each partition, we used grouped land cover variables as outlined in results Section 4.1. We then used all the land cover variables in stepwise linear regression models to identify the land cover variables that explained the most node variance. In the runoff presence and absence analyses, we only included rainfall events during which stream stage heights were monitored, including instances when the corresponding rainfall did not generate runoff.

We regressed solute concentrations against $Q_{t}$, runoff ratio, $P_{\text {depth }}$ and the aforementioned land cover variables to identify 
how solute responses varied in response to rainfall, runoff and land cover. We then performed an exploratory factor analysis (DeCoster, 1998) on solute concentration to land cover correlations. Exploratory factor analysis follows the same steps as a principal component analysis (PCA) in which orthogonal components with Eigen values $>1$, and individually explaining at least $10 \%$ of the data variance (or at least $85 \%$ cumulative data variance) were retained for further interpretation. The retained principal components were then transformed using a varimax rotation to produce orthogonal factor vectors that highlighted the variables that weighed most heavily into each component (Kaiser, 1958; Lehman et al., 2005). The purpose of the factor rotation was to make the results of the PCA easier to interpret. Land cover, rainfall and runoff characteristics with factor loadings $>0.5$ were considered to heavily weigh into that factor; those with factor loadings greater than 0.5 for more than one factor vector were excluded from further interpretation. We clustered the factor scores for each solute using a 2-way Wards Clustering analysis (Sall et al., 2007; Tan et al., 2005) on non-standardized correlations in order to identify groups of solutes with similar loadings to each factor. Because cluster analysis is a statistical pattern recognition approach, there are no data structure requirements. Clustering identifies distinct groups of solutes that within each group have similar hydrochemical responses, therefore enhancing our understanding of the mechanisms that control runoff quality. The loadings indicate the direction and magnitude of the response, and each factor represents a potential controlling mechanism. For interpretation, we retained clusters showing a minimum Euclidian distance of 2.9 between them, which was the distance that most clearly separated the clusters.

\section{Results}

\subsection{Catchment characterization}

The LD site had the largest proportion of low-density residential housing (87.6\%) and the lowest percent impervious cover (21.8\%), while MD had the largest percent of medium-density residential housing (80.6\%) and the lowest stormwater drainage system density $\left(1.98 \mathrm{~km} \mathrm{~km}^{-2}\right.$, Table 1$)$. Here we note that the stormwater drainage network in the Tucson Metro area is a stand-alone system and does not share any structures with the sewer system. Catchment HD had the highest percent high-density residential housing (68.7\%), road density $\left(20.76 \mathrm{~km} \mathrm{~km}^{-2}\right)$ and stormwater drainage system density $\left(6.27 \mathrm{~km} \mathrm{~km}^{-2}\right)$. The largest catchment was MX $\left(4.70 \mathrm{~km}^{2}\right)$, which had the most even distribution of land uses $(L E=0.9)$, while $C M$ was the smallest catchment $\left(0.33 \mathrm{~km}^{2}\right)$ and had the greatest percent impervious cover (90.7\%), commercial land cover (95.7\%) and impervious channel density ( $4.44 \mathrm{~km} \mathrm{~km}^{-2}$ Table 1 ).

With the exception of LD, our study sites were all underlain by Quaternary alluvium (Table 1). The greatest proportion of LD (77\%), and that closest to the outlet, consisted of Quaternary alluvium and late Pliocene/early Pleistocene alluvial fans, while the remaining $23 \%$ farthest from the outlet was composed of conglomerate rock, sandstone, granite and pegmatite (Table 1). Soils are predominately thermic calciargid aridisols and thermic calcerous entisols.

We identified many instances of significant $(p<0.05)$ collinearity among the land cover characteristics. Specifically, percent impervious cover correlated positively with the percent commercial land $\operatorname{cover}\left(r^{2}=0.89\right)$ and impervious channel density $\left(r^{2}=0.91\right)$; percent low density residential correlated positively with catchment slope $\left(r^{2}=0.98\right)$; percent high density residential correlated positively with road density $\left(r^{2}=0.95\right)$; and landscape evenness correlated positively with percent open space $\left(r^{2}=0.86\right)$. Therefore, we reduced the number of land cover variables used in the recursive partitioning analyses to eight variables including: (1) catchment size; (2) pervious channel density; (3) stormwater drainage system density; (4) percent medium density residential; and one variable in the following groupings: (5) $L E$ or percent open space; (6) road density or percent high density residential; (7) percent impervious cover, impervious channel density or percent commercial; and (8) slope or percent low density residential.

\subsection{Monsoonal rainfall and hydrologic responses}

Our sampling spanned a range of rainfall depths throughout the monsoon, with ephemeral runoff only occurring in response to

Table 1

Land cover characteristics of the study catchments.

\begin{tabular}{|c|c|c|c|c|c|}
\hline & \multicolumn{5}{|l|}{ Study catchment } \\
\hline & Low density (LD) & Medium density (MD) & High density (HD) & Mixed (MX) & Commercial (CM) \\
\hline Catchment area $\left(\mathrm{km}^{2}\right)$ & 4.44 & 0.45 & 0.35 & 4.70 & 0.33 \\
\hline \multicolumn{6}{|l|}{ Geology (\%) } \\
\hline Quaternary sand and gravel & 17 & 100 & 100 & 100 & 100 \\
\hline Late Pliocene to early Pleistocene gravel and sand & 60 & 0 & 0 & 0 & 0 \\
\hline Oligocene to middle Miocene conglomerate and sandstone & 19 & 0 & 0 & 0 & 0 \\
\hline Late Cretaceous to early Tertiary granite and pegmatite & 3 & 0 & 0 & 0 & 0 \\
\hline Impervious cover (\%) & 21.84 & 40.64 & 54.48 & 45.78 & 90.70 \\
\hline \multicolumn{6}{|l|}{ Land cover $(\%)$} \\
\hline \multicolumn{6}{|l|}{ Residential housing } \\
\hline Low density & 87.6 & 0.1 & 0.7 & 11.4 & 0.3 \\
\hline Medium density & $<1$ & 80.6 & 19.9 & 43.3 & 2.1 \\
\hline High density & 7.3 & 16.7 & 68.7 & 17.3 & 0 \\
\hline Commercial (office, retail, roads) & 5.0 & 2.6 & 6.4 & 19.8 & 95.7 \\
\hline Open space (parks, agriculture, undeveloped) & $<1$ & 0 & 4.2 & 8.3 & 1.9 \\
\hline Landscape evenness & 0.29 & 0.42 & 0.58 & 0.89 & 0.16 \\
\hline Catchment slope (\%) & 5.6 & 1.2 & 2.2 & 1.9 & 1.5 \\
\hline Road density $\left(\mathrm{km} \mathrm{km}^{-2}\right)$ & 6.58 & 13.30 & 20.76 & 11.68 & 6.19 \\
\hline Stormwater drainage system density $\left(\mathrm{km} \mathrm{km}^{-2}\right)^{\mathrm{a}}$ & 2.81 & 1.98 & 6.27 & 3.97 & 4.44 \\
\hline Pervious channel density $\left(\mathrm{km} \mathrm{km}^{-2}\right)$ & 2.56 & 0 & 2.84 & 0.77 & 0 \\
\hline Impervious channel density $\left(\mathrm{km} \mathrm{km}^{-2}\right)^{\mathrm{b}}$ & 0.25 & 1.98 & 3.42 & 3.20 & 4.44 \\
\hline
\end{tabular}

a Includes pervious and impervious channels and subsurface pipes and culverts.

b Includes impervious above ground waterways and subsurface pipes. 
rainfall. No dry weather flows were observed. Cumulative rainfall, runoff depth and water quality sampling events over the study period are illustrated in Fig. 2. The official duration of the Monsoon season is from June 15th to September 15th; however, the onset and end of monsoonal rainfall can vary from year to year. Monsoonal rainfall events were observed earlier and ended later in
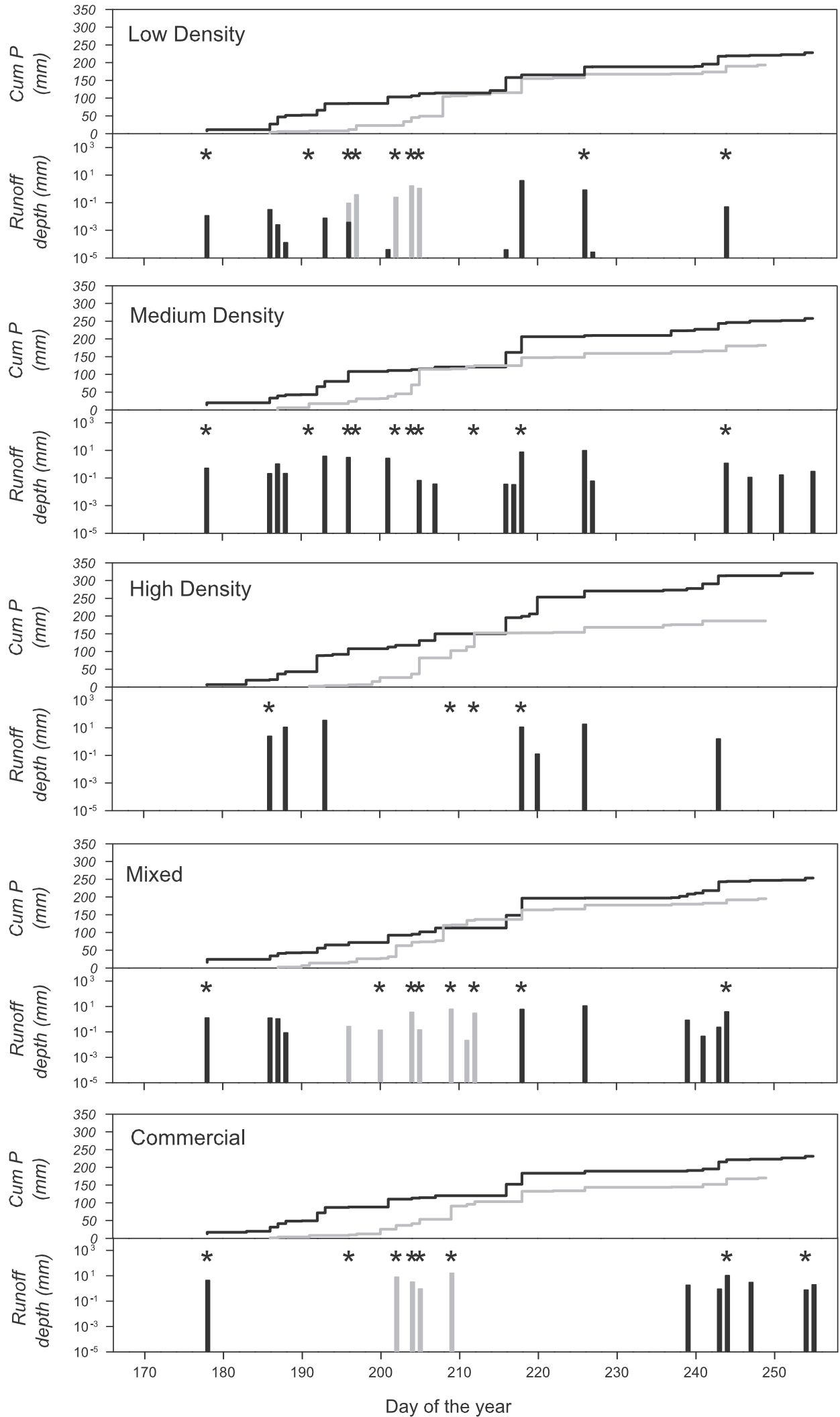

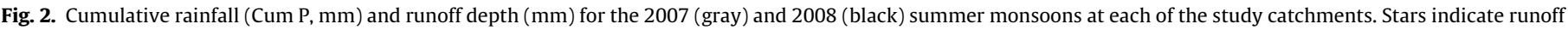
events during which water quality samples were collected. Runoff depth for 2007 at the medium and high density sites is not available. 
the season during 2008 compared to 2007 (Fig. 2). Across sites, there were significantly more days between the first and last monsoonal rainfall events in 2008 ( $77.4 \pm<0.1$ days) than in 2007 $(61.1 \pm 2.2$ days), and significantly more rainfall events in 2008 $(28.4 \pm 1.5)$ than in $2007(22.2 \pm 1.5)$, therefore, average seasonal rainfall was significantly higher in $2008(258.1 \pm 37.3 \mathrm{~mm}$, std dev) than 2007 (186.3 $\pm 10.1 \mathrm{~mm})$. However, we did not observe significant differences across sites or years in monsoonal rainfall event $P_{\text {depth }}(8.9 \pm 10.3 \mathrm{~mm})$, duration $(0.95 \pm 0.93 \mathrm{~h})$, intensity $\left(14.9 \pm 17.7 \mathrm{~mm} \mathrm{~h}^{-1}\right)$ or frequency $\left(0.37 \pm 0.10\right.$ events day $^{-1}$; Table 2 ). In agreement with long-term regional data (Western Regional Climate Center), $P_{\text {depth }}$ ranged from 0.3 to $55 \mathrm{~mm}$, with small $P_{\text {depth }}$ (e.g. $0.3 \mathrm{~mm}$ ) likely resulting from the spatial averaging of highly spatially heterogeneous rainfall. The rainfall intensities that we report here are comparable to those reported by Mendez et al. (2003) for a $60 \mathrm{~min}$ rainfall event, which was the approximate mean duration of rainfall at our sites. Because rainfall characteristics were not significantly different between years, we pooled runoff and rainfall observations made during runoff monitoring to examine spatial controls on runoff quantity and quality. Temporal controls on runoff quantity and quality are addressed in Gallo et al. (2012).

Of 116 rainfall events during which rainfall and streamflow were concurrently monitored, runoff was observed $65 \%$ of the time, ranging from $61 \%$ to $81 \%$ of the time across sites, and did not show distinct trends with land use (Table 2). Recursive partitioning analysis for "runoff/no runoff" responses (Fig. 3) showed that across sites, when $P_{\text {depth }} \geqslant 6.4 \mathrm{~mm}$, runoff was always observed. At $P_{\text {depth }}<6.4 \mathrm{~mm}$, land cover variables coupled with rainfall depth largely controlled the presence of runoff. For example, no runoff was observed when $P_{\text {depth }}<6.4 \mathrm{~mm}$ and pervious channel density $\geqslant 2.84 \mathrm{~km} \mathrm{~km}^{-2}$. However, when pervious channel density $<2.84 \mathrm{~km} \mathrm{~km}^{-2}$ and $P_{\text {depth }}$ ranged between 3.2 and $6.4 \mathrm{~mm}$, runoff was observed $75 \%$ of the time and catchment size largely controlled "runoff/no runoff" responses.

Runoff depth (mm) and runoff ratios (\%) were significantly lower at $\mathrm{LD}(0.4 \mathrm{~mm}$ and $3.1 \%$, respectively) than $\mathrm{HD}(10.0 \mathrm{~mm}$ and $34.4 \%$ ) and CM (4.7 mm and 37.9; Table 2; Fig. 4a and b). We observed significantly shorter runoff duration at LD $(2.2 \mathrm{~h})$ than at MD (4.7 h) and CM (4.5 h, Table 2 and Fig. 4c), while time to peak discharge was significantly different only between MX (0.8 h) and CM (0.3 h, Table 2, Fig. 4d). Runoff depth, runoff ratio and runoff duration correlated significantly with a number of climate and land use variables including $P_{\text {depth }}(r=0.65,0.33$ and 0.39 , respectively) and percent impervious cover $(r=0.45,0.71$ and 0.30$)$; while time to peak discharge correlated significantly with $L E(r=0.41)$ and road density ( $r=0.26$, Table 3 ) among others. However, less than $50 \%$ of the variance in runoff depth, runoff ratio, runoff duration or time to peak discharge was explained by $P_{\text {depth }}$ or any other land cover variable.

The recursive partitioning and stepwise linear regression analysis showed that runoff depth responses to land cover characteristics, specifically, percent impervious cover, varied at specific $P_{\text {depth }}$ thresholds. At $P_{\text {depth }}>35.4 \mathrm{~mm}$, for example, $85 \%$ of the runoff depth variance was significantly explained by percent impervious cover and catchment size; percent impervious cover significantly explained $53 \%$ of the runoff depth variance when $P_{\text {depth }}$ ranged between 10.8 and $35.4 \mathrm{~mm}$; while at $P_{\text {depth }}<10.8 \mathrm{~mm}$, percent impervious cover, road density and $P_{\text {depth }}$ significantly explained $65 \%$ of runoff depth variance (Fig. $5 a$ ). We identified similar thresholds for runoff ratios, where at $P_{\text {depth }}>10.7 \mathrm{~mm}, 56 \%$ of the runoff ratio variance was explained by percent impervious cover (Fig. 5b). At $P_{\text {depth }}<10.7$, the combined effect of percent impervious cover and road density significantly explained $75 \%$ of the runoff ratio variance (Fig. 5b). We did not identify any significant response thresholds in runoff duration or time to peak discharge, and multiple linear regression models did not explain any more time to peak discharge and runoff duration variance than individual land cover variables.

\subsection{Runoff quality responses}

Streamflow responses during our monitoring period were spatially and temporally heterogeneous (Fig. 2). While streamflow did not occur at all sites in response to the same rainfall event or on the same date, over our 2 years of sampling we collected runoff samples throughout the summer monsoon. Indeed, a total of 293 runoff samples were collected (Table 4 ) from 39 streamflow events distributed throughout the two monsoon seasons (Fig. 2).

Across our sites, mean seasonal solute concentrations were highly variable and did not display a single dominant water quality pattern (Table 4). For example, concentrations of $\mathrm{Cl}$, a conservative hydrologic tracer, were significantly higher at $\mathrm{CM}\left(10.5 \mathrm{mg} \mathrm{L}^{-1}\right)$ compared to the other sites (Fig. 6a). Concentrations of $\mathrm{Zn}$ were

Table 2

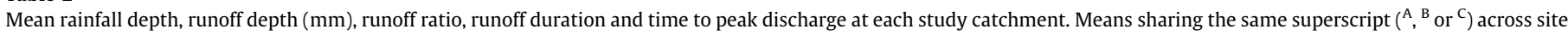
columns are not significantly different from each other.

\begin{tabular}{|c|c|c|c|c|c|c|}
\hline & & Low density (LD) & Medium density (MD) & High density (HD) & Mixed (MX) & Commercial (CM) \\
\hline $\begin{array}{l}\text { Rainfall } \\
\text { Days between first and last event }\end{array}$ & $\begin{array}{l}2007 \\
2008\end{array}$ & $\begin{array}{l}62.4 \\
77.3\end{array}$ & $\begin{array}{l}61.5 \\
77.3\end{array}$ & $\begin{array}{l}57.3 \\
77.3\end{array}$ & $\begin{array}{l}61.6 \\
77.3\end{array}$ & $\begin{array}{l}62.4 \\
77.3\end{array}$ \\
\hline Total number of rainfall events & $\begin{array}{l}2007 \\
2008\end{array}$ & $\begin{array}{l}23 \\
28\end{array}$ & $\begin{array}{l}22 \\
27\end{array}$ & $\begin{array}{l}20 \\
27\end{array}$ & $\begin{array}{l}24 \\
30\end{array}$ & $\begin{array}{l}22 \\
26\end{array}$ \\
\hline Frequency (events per day) & $\begin{array}{l}2007 \\
2008\end{array}$ & $\begin{array}{l}0.37 \\
0.36\end{array}$ & $\begin{array}{l}0.36 \\
0.35\end{array}$ & $\begin{array}{l}0.35 \\
0.35\end{array}$ & $\begin{array}{l}0.39 \\
0.39\end{array}$ & $\begin{array}{l}0.35 \\
0.34\end{array}$ \\
\hline $\begin{array}{l}\text { Depth }(\mathrm{mm}, \min , \max ) \\
\text { Duration }\left(\mathrm{h}^{-1}\right) \\
\text { Intensity }\left(\mathrm{mm} \mathrm{h}^{-1}\right)\end{array}$ & & $\begin{array}{l}8.2(0.1-55.8)^{\mathrm{A}} \\
1.1(0.1-3.9)^{\mathrm{A}} \\
14.8(0.3-87.3)^{\mathrm{A}}\end{array}$ & $\begin{array}{l}9.3(0.3-44.5)^{\mathrm{A}} \\
1.4(0.1-5.7)^{\mathrm{A}} \\
10.6(0.3-45.1)^{\mathrm{A}}\end{array}$ & $\begin{array}{l}10.6(0.3-47.4)^{\mathrm{A}} \\
0.7(<0.1-3.5)^{\mathrm{A}} \\
16.4(0.6-47.2)^{\mathrm{A}}\end{array}$ & $\begin{array}{l}8.6(0.3-48.3)^{\mathrm{A}} \\
1.1(0.1-4)^{\mathrm{A}} \\
12.1(0.5-58.2)^{\mathrm{A}}\end{array}$ & $\begin{array}{l}8.3(0.6-35.4)^{\mathrm{A}} \\
1.2(0.1-4)^{\mathrm{A}} \\
14.7(0.3-77.4)^{\mathrm{A}}\end{array}$ \\
\hline Total rainfall-runoff events monitored & & 31 & $21^{\mathrm{a}}$ & $19^{\mathrm{a}}$ & 29 & 16 \\
\hline $\begin{array}{l}\text { Runoff } \\
\text { Events where runoff depth }=0 \\
\text { Events where runoff depth }>0\end{array}$ & & $\begin{array}{l}11(35 \%) \\
20(65 \%)\end{array}$ & $\begin{array}{l}4(19 \%)^{\mathrm{a}} \\
17(81 \%)^{\mathrm{a}}\end{array}$ & $\begin{array}{l}11(58 \%)^{\mathrm{a}} \\
8(42 \%)^{\mathrm{a}}\end{array}$ & $\begin{array}{l}11(38 \%) \\
18(62 \%)\end{array}$ & $\begin{array}{l}4(25 \%) \\
12(75 \%)\end{array}$ \\
\hline $\begin{array}{l}\text { Runoff depth (mm, min-max) } \\
\text { Runoff ratio (\%, min-max) }\end{array}$ & & $\begin{array}{l}0.4(<0.1-4.0)^{\mathrm{C}} \\
3.1(<0.1-15.6)^{\mathrm{C}}\end{array}$ & $\begin{array}{l}1.8(<0.1-9.9)^{\mathrm{BC}} \\
8.0(0.6-22.3)^{\mathrm{B}}\end{array}$ & $\begin{array}{l}10.0(0.1-23.9)^{\mathrm{A}} \\
34.4(2.0-76.7)^{\mathrm{A}}\end{array}$ & $\begin{array}{l}2.2(<0.1-11.3)^{\mathrm{BC}} \\
9.6(1.2-23.6)^{\mathrm{B}}\end{array}$ & $\begin{array}{l}4.7(0.8-16)^{\mathrm{AB}} \\
37.9(18.5-61.8)^{\mathrm{A}}\end{array}$ \\
\hline $\begin{array}{l}\text { Time to peak discharge (h, min-max) } \\
\text { Runoff duration (h, min-max) }\end{array}$ & & $\begin{array}{l}0.5(0.1-1.7)^{\mathrm{AB}} \\
2.2(0.3-7.4)^{\mathrm{B}}\end{array}$ & $\begin{array}{l}0.5(0.1-1.4)^{\mathrm{AB}} \\
4.7(2.2-8.9)^{\mathrm{A}}\end{array}$ & $\begin{array}{l}0.8(0.4-1.3)^{\mathrm{AB}} \\
4.4(2.4-8.7)^{\mathrm{AB}}\end{array}$ & $\begin{array}{l}0.8(0.1-2.1)^{\mathrm{A}} \\
3.9(0.9-7.5)^{\mathrm{AB}}\end{array}$ & $\begin{array}{l}0.3(0.2-0.6)^{\mathrm{B}} \\
4.5(1.5-6.4)^{\mathrm{A}}\end{array}$ \\
\hline
\end{tabular}

a Data available for 2008 only. 


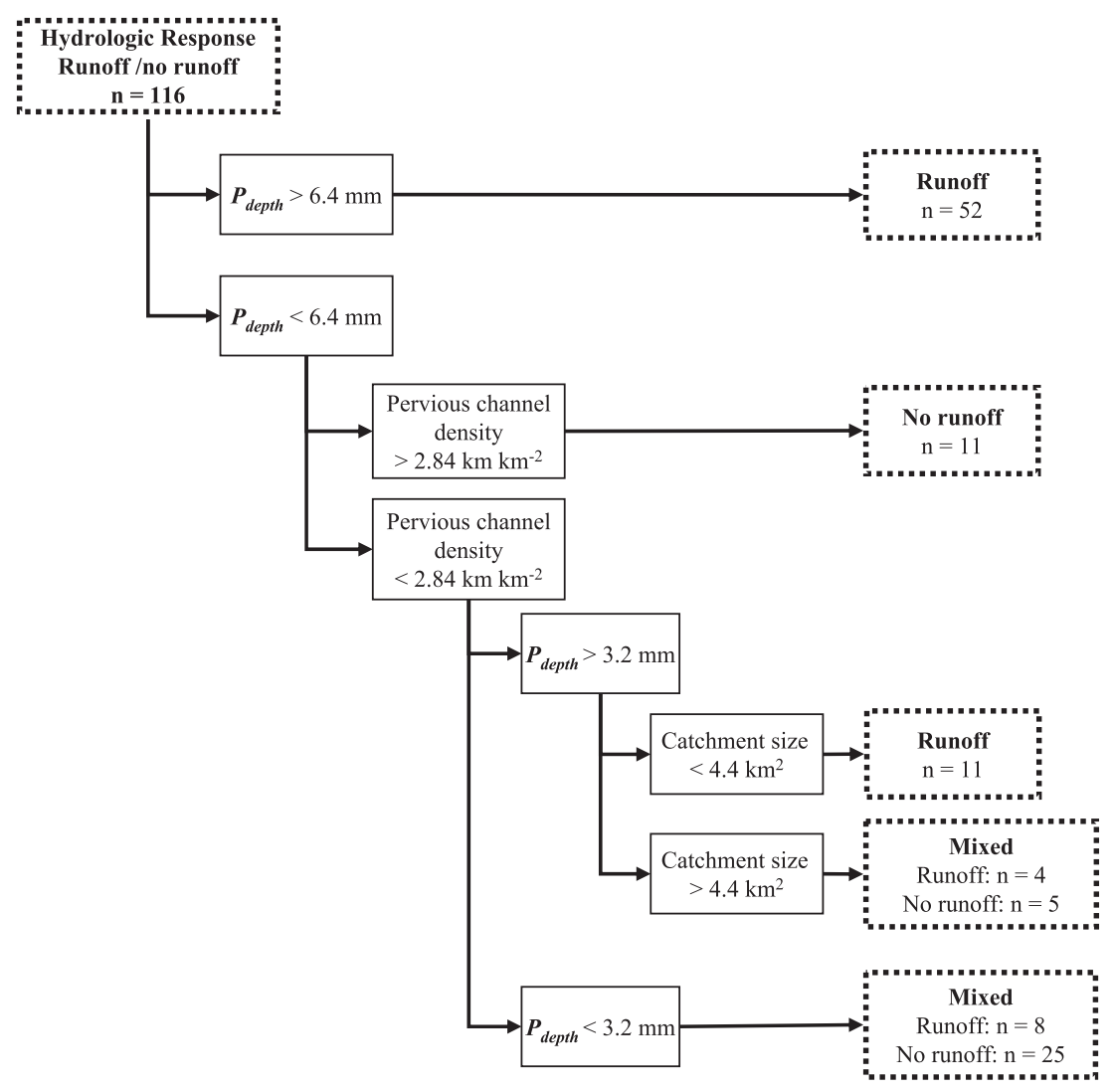

Fig. 3. Partition tree for streamflow thresholds across our study sites. This decision model has $r^{2}$ of 0.68 .
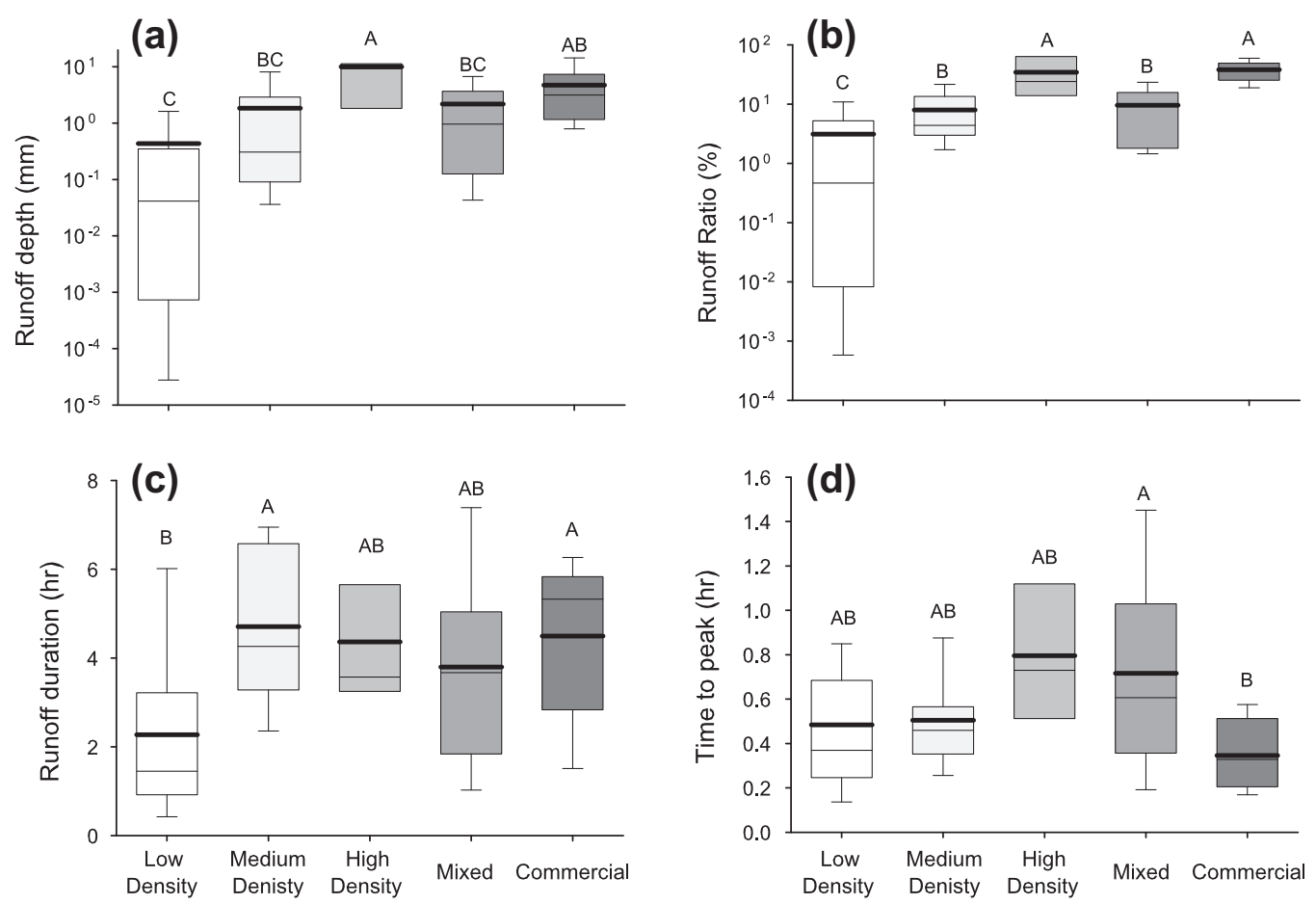

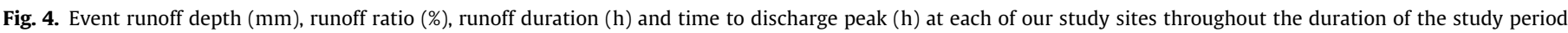

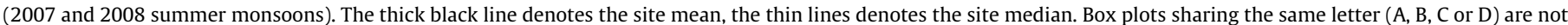
significantly different from each other.

also significantly higher at $\mathrm{CM}$ (and $112.2 \mu \mathrm{g} \mathrm{L}^{-1}$ ) compared to other sites, but were significantly lower at HD and MX than at LD of MD (Fig. 6b). DOC concentrations followed similar trends to $\mathrm{Zn}$ but were not significantly different among $\mathrm{LD}, \mathrm{MD}$ and $\mathrm{CM}$ (Fig. 6c). Finally, concentrations of many solutes including $\mathrm{NO}_{3}$, $\mathrm{Pb}$ and $\mathrm{Ca}$ (Fig. 6d-f), did not vary significantly across sites. 
Table 3

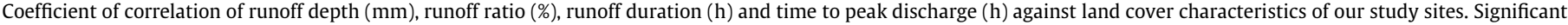
correlations at $p \leqslant 0.05$ are shown, non-significant correlations are noted with a "/".

\begin{tabular}{|c|c|c|c|c|}
\hline & Runoff depth & Runoff ratio & Time to peak discharge & Runoff duration \\
\hline Catchment size & -0.37 & -0.48 & 1 & -0.34 \\
\hline Impervious cover (\%) & 0.45 & 0.71 & i & 0.30 \\
\hline \multicolumn{5}{|l|}{ Land cover (\%) } \\
\hline Low density & -0.35 & -0.42 & 1 & -0.44 \\
\hline Medium density & 1 & 1 & i & 0.31 \\
\hline High density & 0.26 & i & 0.25 & 1 \\
\hline Commercial & 0.33 & 0.64 & 1 & i \\
\hline Open space & 1 & 1 & 0.35 & i \\
\hline Landscape evenness & 1 & -0.23 & 0.41 & 1 \\
\hline Catchment slope (\%) & -0.30 & -0.38 & 1 & -0.45 \\
\hline Road density $\left(\mathrm{km} \mathrm{km}^{-2}\right)$ & 1 & 1 & 0.26 & 1 \\
\hline Stormwater drainage system density $\left(\mathrm{km} \mathrm{km}^{-2}\right)$ & 0.42 & 0.46 & 1 & 1 \\
\hline Pervious channel density $\left(\mathrm{km} \mathrm{km}^{-2}\right)$ & 1 & -0.27 & 1 & -0.40 \\
\hline Impervious channel density $\left(\mathrm{km} \mathrm{km}^{-2}\right)$ & 0.44 & 0.60 & 1 & 0.33 \\
\hline
\end{tabular}

(a)

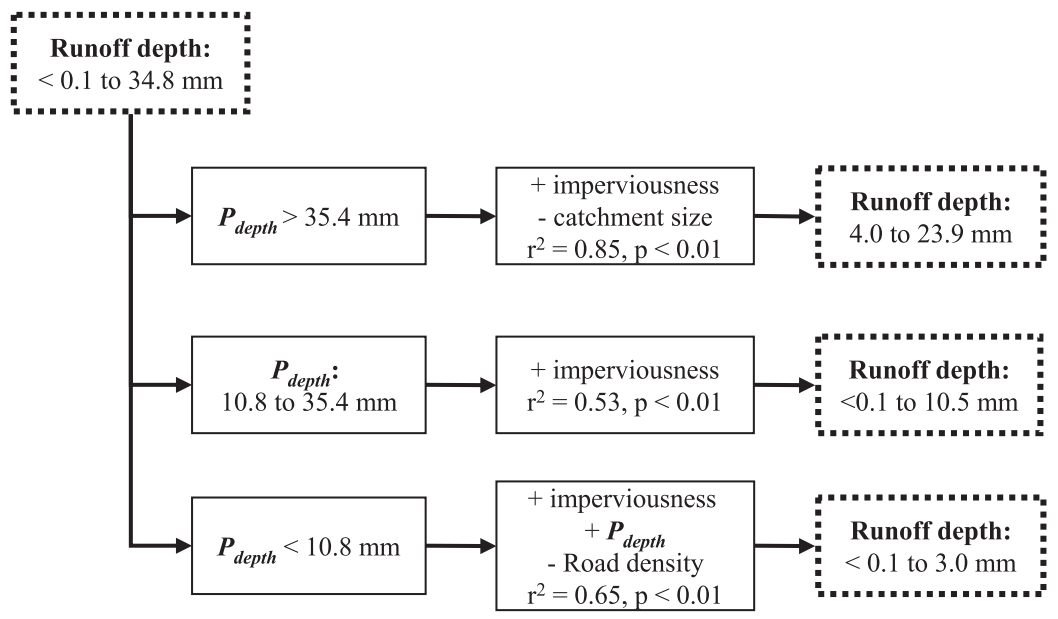

(b)

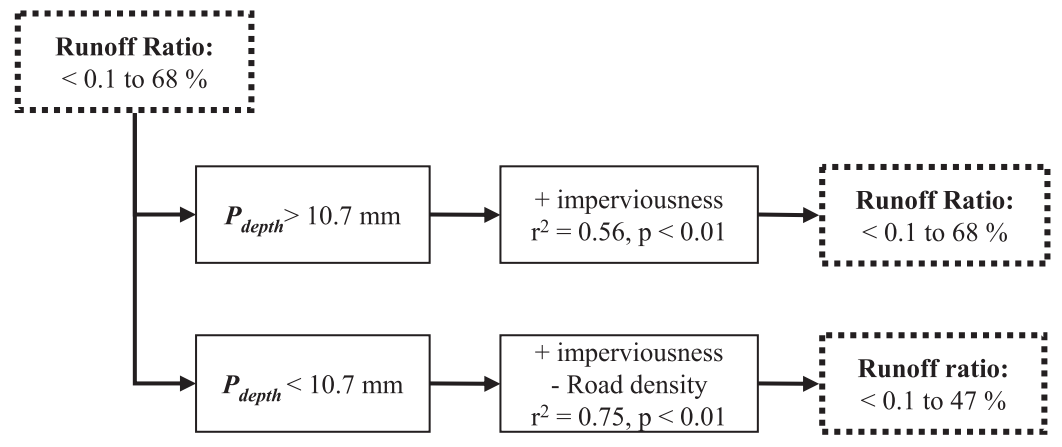

Fig. 5. Recursive partitioning for event runoff depth (decision tree, a) and runoff ratio (decision tree, b).

Although 17 out of 24 solutes showed significant log-log correlations of solute concentrations to $P_{\text {depth }}$ and $Q_{t}$, we found that with the exception of $\mathrm{Hg}\left(P_{\text {depth }} r=-0.73\right)$, these correlations could only explain up to $35 \%$ of the variance in solute concentrations (Table 5 ). Land cover variables explained even less variation in solute concentrations, only as much as $17 \%$ (linear correlations, Table 5 ). Most solute concentrations significantly decreased with increasing $P_{\text {depth }}$ and $Q_{t}$, with the exception of $\mathrm{NO}_{3}$ and SRP, which significantly increased with $Q_{t}$. Solutes, $\mathrm{Ni}$ and $\mathrm{Hg}$, did not significantly correlate with any catchment characteristic, while E. coli, which did not vary with $Q_{t}$ or runoff ratio, was correlated significantly and positively with percent open space and stormwater drainage system density.
We used factor analysis to identify four main land cover groupings that could account for $95 \%$ of the variance in our data set (Table 6). Road density, the percent medium and high density residential and $L E$ loaded onto Factor 1 (factor loadings $=0.97$, $0.85,0.94$ and 0.92 , respectively), while pervious channel density, catchment size, slope and percent low density residential loaded most heavily onto Factor 2 (factor loadings = 0.96, 0.94, 0.73 and 0.68 , respectively). The stormwater drainage system density, impervious channel density, percent impervious cover and the percent commercial land cover loaded onto Factor 3 (factor loadings $=0.94,0.84,0.69$ and 0.51 , respectively), while runoff depth and runoff ratio loaded onto Factor 4 (factor loadings $=0.80$ and 0.87). 
Table 4

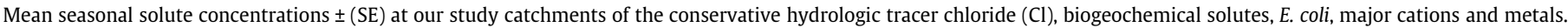
Solute concentrations sharing the same superscript $\left({ }^{\mathrm{A}},{ }^{\mathrm{B}}\right.$ or $\left.{ }^{\mathrm{C}}\right)$ across site columns are not significantly different from each other $(p>0.05)$.

\begin{tabular}{|c|c|c|c|c|c|}
\hline Solute & Low density (LD) & Medium density (MD & High density (HD) & Mixed (MX) & Commercial (CM) \\
\hline $\begin{array}{l}\text { Number } \\
2007 \\
2008\end{array}$ & $\begin{array}{l}6,21^{\mathrm{a}} \\
3,29^{\mathrm{a}}\end{array}$ & $\begin{array}{l}7,45^{\mathrm{a}} \\
3,36^{\mathrm{a}}\end{array}$ & $\begin{array}{l}2,24^{\mathrm{a}} \\
2,24^{\mathrm{a}}\end{array}$ & $\begin{array}{l}5,29^{\mathrm{a}} \\
3,31^{\mathrm{a}}\end{array}$ & $\begin{array}{l}5,36^{\mathrm{a}} \\
3,18^{\mathrm{a}}\end{array}$ \\
\hline $\begin{array}{l}\text { Solute } \\
\mathrm{Cl}^{\mathrm{b}} \\
\mathrm{NO}_{2}{ }^{\mathrm{b}} \\
\mathrm{NO}_{3}{ }^{\mathrm{b}} \\
\mathrm{NH}_{4}{ }^{\mathrm{b}}\end{array}$ & $\begin{array}{l}7.0(1.2-19.2)^{\mathrm{B}} \\
0.2(<0.1-1.8)^{\mathrm{A}} \\
1.0(<0.1-3.5)^{\mathrm{A}} \\
0.8(<0.1-1.9)^{\mathrm{A}}\end{array}$ & $\begin{array}{l}4.0(1.4-12.5)^{\mathrm{B}} \\
0.2(<0.1-0.9)^{\mathrm{A}} \\
0.9(<0.1-2.0)^{\mathrm{A}} \\
0.8(0.2-2.6)^{\mathrm{A}}\end{array}$ & $\begin{array}{l}2.6(1.3-5.7)^{\mathrm{B}} \\
0.1(<0.1-0.6)^{\mathrm{A}} \\
0.8(<0.1-1.8)^{\mathrm{A}} \\
0.5(<0.1-1.4)^{\mathrm{A}}\end{array}$ & $\begin{array}{l}3.4(1.2-6.6)^{\mathrm{B}} \\
0.1(<0.1-0.9)^{\mathrm{A}} \\
0.8(<0.1-2)^{\mathrm{A}} \\
0.5(0.1-1.2)^{\mathrm{A}}\end{array}$ & $\begin{array}{l}10.5(1.8-38.7)^{\mathrm{A}} \\
0.4(<0.1-4.0)^{\mathrm{A}} \\
1.0(<0.1-3.0)^{\mathrm{A}} \\
1.0(<0.1-4.6)^{\mathrm{A}}\end{array}$ \\
\hline $\begin{array}{l}\mathrm{DON}^{\mathrm{b}} \\
\mathrm{SRP}^{\mathrm{b}} \\
\mathrm{SO}_{4}^{\mathrm{b}} \\
\mathrm{DOC}^{\mathrm{b}}\end{array}$ & $\begin{array}{l}2.5(<0.1-10)^{\mathrm{A}} \\
0.1(<0.1-0.2)^{\mathrm{B}} \\
6.0(0.5-16.6)^{\mathrm{A}} \\
55.0(5.3-203)^{\mathrm{A}}\end{array}$ & $\begin{array}{l}1.2(<0.1-5.1)^{\mathrm{A}} \\
0.1(<0.1-0.2)^{\mathrm{AB}} \\
2.4(<0.1-11.6)^{\mathrm{B}} \\
24.0(4.4-88.1)^{\mathrm{A}}\end{array}$ & $\begin{array}{l}0.5(<0.1-2.3)^{\mathrm{A}} \\
0.1(<0.1-0.3)^{\mathrm{A}} \\
1.7(0.9-4.3)^{\mathrm{B}} \\
7.0(2.2-18.6)^{\mathrm{B}}\end{array}$ & $\begin{array}{l}0.5(<0.1-3.5)^{\mathrm{A}} \\
0.1(<0.1-0.4)^{\mathrm{AB}} \\
1.9(0.9-4.4)^{\mathrm{B}} \\
10.2(2.4-45.9)^{\mathrm{B}}\end{array}$ & $\begin{array}{l}1.7(<0.1-10.0)^{\mathrm{A}} \\
0.2(<0.1-0.9)^{\mathrm{A}} \\
5.4(1.0-17.9)^{\mathrm{A}} \\
27.9(6.5-147.0)^{\mathrm{A}}\end{array}$ \\
\hline $\begin{array}{l}\text { E. } \operatorname{coll}^{\mathrm{c}, \mathrm{e}} \\
\mathrm{Ca}^{\mathrm{b}} \\
\mathrm{K}^{\mathrm{b}} \\
\mathrm{Mg}^{\mathrm{b}}\end{array}$ & $\begin{array}{l}7.0(<0.1-69.5)^{\mathrm{A}} \\
14.5(8.0-38.8)^{\mathrm{A}} \\
4.1(1.6-12.6)^{\mathrm{A}} \\
1.4(0.6-3.9)^{\mathrm{AB}}\end{array}$ & $\begin{array}{l}0.1(<0.1-0.2)^{\mathrm{B}} \\
14.6(7.7-30.4)^{\mathrm{A}} \\
4.7(2.0-12.1)^{\mathrm{A}} \\
1.6(0.8-3)^{\mathrm{A}}\end{array}$ & $\begin{array}{l}\text { n.a. } \\
13.8(10.6-17.8)^{\mathrm{A}} \\
2.7(2.0-3.9)^{\mathrm{A}} \\
1.2(0.8-1.7)^{\mathrm{AB}}\end{array}$ & $\begin{array}{l}25.3(0.3-73.9)^{\mathrm{A}} \\
12.7(7.9-20.6)^{\mathrm{A}} \\
3.7(1.4-9.1)^{\mathrm{A}} \\
1.1(0.6-2)^{\mathrm{B}}\end{array}$ & $\begin{array}{l}13.1(1.0-84.0)^{\mathrm{A}} \\
17.4(6.0-63.9)^{\mathrm{A}} \\
4.1(1.3-13.9)^{\mathrm{A}} \\
1.5(0.4-5.8)^{\mathrm{AB}}\end{array}$ \\
\hline $\begin{array}{l}\mathrm{Na}^{\mathrm{b}} \\
\mathrm{Al}^{\mathrm{b}} \\
\mathrm{V}^{\mathrm{d}} \\
\mathrm{As}^{\mathrm{d}}\end{array}$ & $\begin{array}{l}5.7(2.5-20.9)^{\mathrm{AB}} \\
0.4(0.2-1.1)^{\mathrm{AB}} \\
5.6(2.1-15.7)^{\mathrm{ABC}} \\
1.4(0.2-2.9)^{\mathrm{A}}\end{array}$ & $\begin{array}{l}4.0(2.3-8.3)^{\mathrm{BC}} \\
0.6(0.2-1.7)^{\mathrm{A}} \\
6.5(2.3-17.4)^{\mathrm{AB}} \\
1.7(0.9-3.6)^{\mathrm{A}}\end{array}$ & $\begin{array}{l}3.6(2.4-4.9)^{\mathrm{ABC}} \\
0.4(0.2-0.9)^{\mathrm{AB}} \\
3.3(2.5-4.4)^{\mathrm{C}} \\
1.9(1.0-2.7)^{\mathrm{A}}\end{array}$ & $\begin{array}{l}3.7(2.0-7.4)^{\mathrm{C}} \\
0.5(0.2-1.1)^{\mathrm{AB}} \\
4.5(2.2-10.8)^{\mathrm{BC}} \\
1.9(0.9-6.6)^{\mathrm{A}}\end{array}$ & $\begin{array}{l}10.5(2.1-74.1)^{\mathrm{A}} \\
0.4(<0.1-1.2)^{\mathrm{B}} \\
7.7(2.8-31.1)^{\mathrm{A}} \\
1.7(0.6-4.7)^{\mathrm{A}}\end{array}$ \\
\hline $\begin{array}{l}\mathrm{Cd}^{\mathrm{d}} \\
\mathrm{Co}^{\mathrm{d}} \\
\mathrm{Cu}^{\mathrm{d}} \\
\mathrm{Fe}^{\mathrm{b}}\end{array}$ & $\begin{array}{l}0.1(<0.1-0.3)^{\mathrm{A}} \\
1.0(0.1-3.1)^{\mathrm{A}} \\
20.3(3.7-61.3)^{\mathrm{B}} \\
0.7(0.2-7.7)^{\mathrm{A}}\end{array}$ & $\begin{array}{l}0.1(<0.1-0.5)^{\mathrm{A}} \\
1.6(0.1-4.6)^{\mathrm{A}} \\
16.2(3.9-48.7)^{\mathrm{B}} \\
0.6(0.3-1.1)^{\mathrm{A}}\end{array}$ & $\begin{array}{l}<0.1(0-0.1)^{\mathrm{B}} \\
0.9(0.6-1.4)^{\mathrm{A}} \\
7.0(4.5-15.5)^{\mathrm{C}} \\
0.5(0.4-0.6)^{\mathrm{A}}\end{array}$ & $\begin{array}{l}<0.1(<0.1-0.3)^{\mathrm{B}} \\
0.9(0.2-2.4)^{\mathrm{A}} \\
9.9(3.1-33.9)^{\mathrm{C}} \\
0.5(0.2-1.2)^{\mathrm{A}}\end{array}$ & $\begin{array}{l}0.2(<0.1-0.7)^{\mathrm{A}} \\
1.3(0.2-9.2)^{\mathrm{A}} \\
28.8(8.7-69.5)^{\mathrm{A}} \\
0.5(0.1-1.2)^{\mathrm{A}}\end{array}$ \\
\hline $\begin{array}{l}\mathrm{Hg}^{\mathrm{d}, \mathrm{e}} \\
\mathrm{Ni}^{\mathrm{d}} \\
\mathrm{Pb}^{\mathrm{d}} \\
\mathrm{Zn}^{\mathrm{d}}\end{array}$ & $\begin{array}{l}1.5(0.7-3.1)^{\mathrm{A}} \\
5.6(1.1-16.7)^{\mathrm{A}} \\
1.2(0.1-3.4)^{\mathrm{A}} \\
57.3(5.0-248.5)^{\mathrm{B}}\end{array}$ & $\begin{array}{l}1.4(0.3-3.6)^{\mathrm{A}} \\
8.3(1.3-50.7)^{\mathrm{A}} \\
2.9(0.2-39.2)^{\mathrm{A}} \\
51(6.3-370.1)^{\mathrm{B}}\end{array}$ & $\begin{array}{l}\text { n.a. } \\
6.9(1.6-41.6)^{\mathrm{A}} \\
0.7(0.2-5.2)^{\mathrm{A}} \\
9.4(3.8-19.1)^{\mathrm{C}}\end{array}$ & $\begin{array}{l}0.9(0.3-1.9)^{\mathrm{A}} \\
6.1(0.8-22)^{\mathrm{A}} \\
1.1(0.2-5.1)^{\mathrm{A}} \\
14.5(4.7-59.9)^{\mathrm{C}}\end{array}$ & $\begin{array}{l}1.8(0.6-5.4)^{\mathrm{A}} \\
7.3(1.4-37.9)^{\mathrm{A}} \\
1.5(0.1-17.6)^{\mathrm{A}} \\
112.2(22.6-467.9)^{\mathrm{A}}\end{array}$ \\
\hline
\end{tabular}

a The numbers indicate the number of runoff events sampled and the total number of runoff samples collected through the season, respectively.

b Concentrations in $\mathrm{mg} \mathrm{L}^{-1}$.

c Concentration in $\mathrm{CFU} \mathrm{ml}{ }^{-1}$.

d Concentrations in $\mu \mathrm{g} \mathrm{L}^{-1}$.

e E. coli and $\mathrm{Hg}$ data are not available for HD.

Cluster analysis of factor loadings for each solute identified five specific solute response patterns (Fig. 7, Table 7). Cluster $R 1$ was comprised of $\mathrm{Cl}, \mathrm{Na}$ and $\mathrm{NH}_{4}$ and the metals $\mathrm{V}, \mathrm{Cd}, \mathrm{Cu}$ and $\mathrm{Zn}$. Cluster $R 2$ included $E$. coli and the biogeochemically active anions, $\mathrm{NO}_{2}$, $\mathrm{SRP}$ and $\mathrm{NO}_{3}$; while $\mathrm{R} 3$ was comprised of the biogeochemically active solutes DON, $\mathrm{SO}_{4}$ and DOC. Cluster $R 4$ was comprised of the base cations, $\mathrm{K}$ and $\mathrm{Mg}$, as well as the metals, $\mathrm{Fe}, \mathrm{Pb}, \mathrm{Co}$ and $\mathrm{Al}$, while $\mathrm{Ca}, \mathrm{Ni}$, As and $\mathrm{Hg}$ comprised $\mathrm{R} 5$. The dominant solute behavior patterns highlighted by the factor and cluster analysis indicate that cluster $R 1$ solute concentrations varied negatively with Factors 1 and 2 , while cluster $R 2$ solute concentrations varied positively with Factor 4. Concentrations of $R 3$ solutes varied negatively with Factors 1 and 3, and positively with Factor 2, while concentrations of $R 4$ solutes varied positively with Factor 1 and negatively with Factor 3 and concentrations of $R 5$ solutes varied positively with Factor 3 and negatively with Factor 4.

\section{Discussion}

\subsection{Rainfall and hydrologic responses}

Our findings suggest that in semi-arid catchments, urbanization increases the frequency, magnitude and duration of runoff. Consistent with runoff responses in undeveloped semi-arid catchments, not all monitored rainfall events generated runoff (Houser et al., 2000; Morin et al., 2006). However, measureable runoff was observed up to eight times more frequently in our urbanized study sites than in undeveloped catchments in the region (Gallo, 2011; Resnick et al., 1983; Stone et al., 2008). It is likely that these re- sponses are largely controlled by land cover, rainfall depth and short term (event time scale) rainfall partitioning given that antecedent conditions play a minor role in rainfall-runoff dynamics of semi-arid environments (Gallo et al., 2012; Osborn and Lane, 1969; Syed et al., 2003; Zhang et al., 2011).

Although it is well established that urbanization alters catchment hydrology (for example: ASCE, 1996), few studies document how land cover alters rainfall-runoff responses in arid and semiarid climates (for example: Resnick et al., 1983). Here, urban runoff was always observed at a lower rainfall threshold $\left(P_{\text {depth }}>6.4 \mathrm{~mm}\right)$ than in semi-arid undeveloped catchments $\left(P_{\text {depth }}>20 \mathrm{~mm}\right.$, Gallo, 2011). Lower rainfall-runoff thresholds and higher urban runoff frequency are likely due to (1) higher percent impervious cover which enhances runoff delivery to urban washes, (2) higher road density which, in urban areas like Tucson where roads form part of the overland flow conveyance system (http://rfcd.pima.gov/projects/missionview/), may increase above ground catchment connectivity, and (3) the presence of impervious channels and a low density of pervious channel which may reduce stream channel storage and infiltration losses. Although percent impervious cover and impervious channel density are significantly correlated and it is not possible to separately address their effects on runoff responses, our results indicate that characteristics of the stormwater drainage system have a large effect on the frequency of runoff generation, as has been reported elsewhere (Meierdiercks et al., 2010; Ogden et al., 2011; Walsh et al., 2005a).

At smaller $P_{\text {depth }}(<6.4 \mathrm{~mm})$, our study suggests that water losses to catchment storage largely control the frequency of urban runoff given that in undeveloped water limited catchments, runoff infiltration losses increase with catchment size, stream channel length 

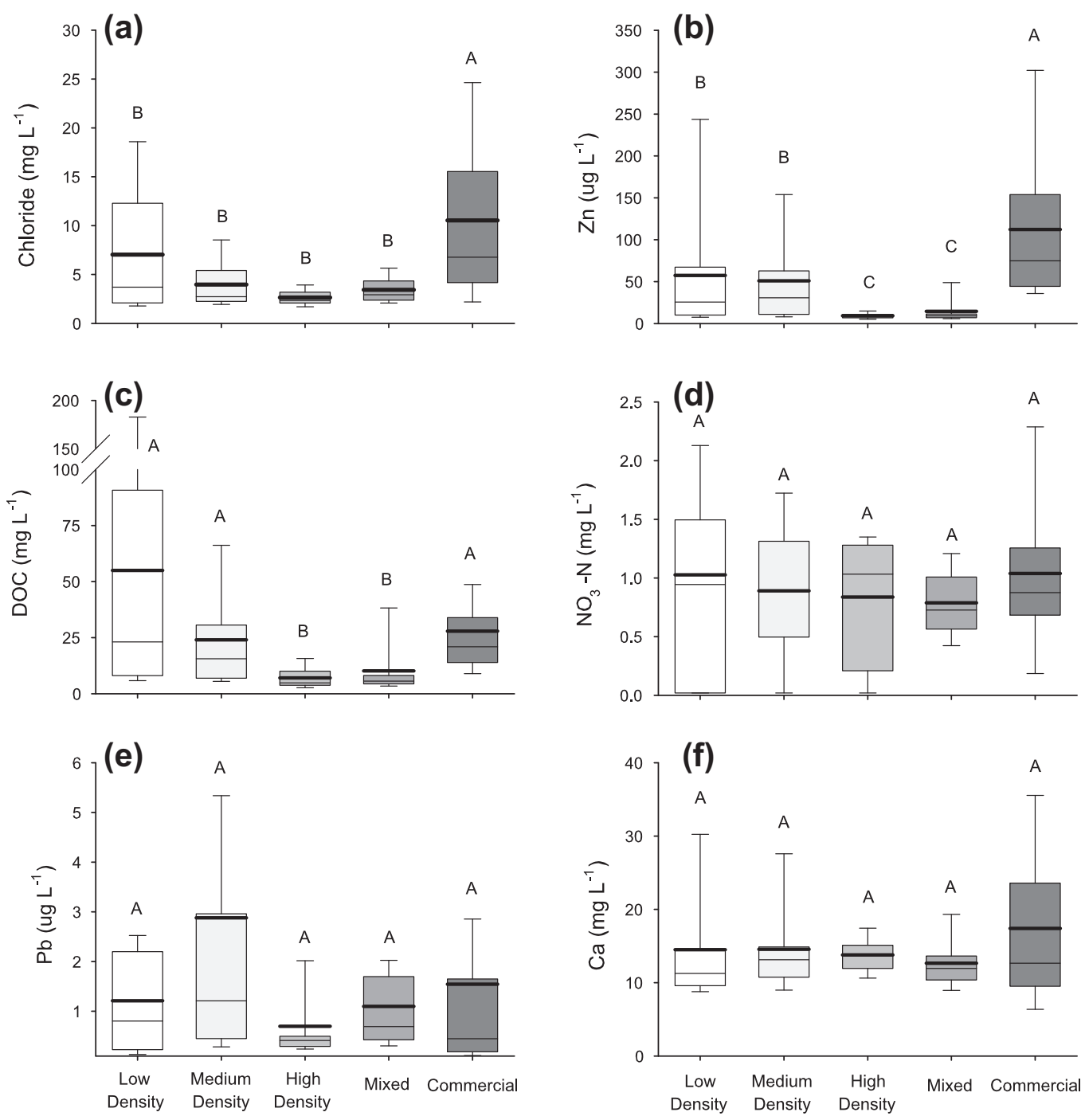

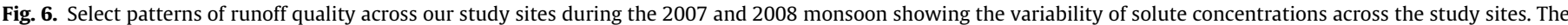

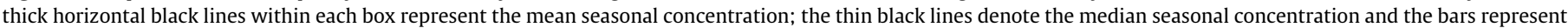
the 5 th and 95th percentiles. Boxplots sharing the same letter (A, B or C) are not significantly different from each other.

and distance from the catchment outlet (Loik et al., 2004). However, further work should assess how urban runoff frequency varies in response to the spatial distribution of rainfall, an important control of catchment hydrology in the semi-arid Southwest (Goodrich et al., 1997; Morin et al., 2006).

The runoff depths and runoff ratios measured in this study are comparable to those reported for urban catchments of the Tucson Basin (Resnick et al., 1983) and other arid and semi-arid regions (Gibson et al., 2008; Ishaq, 1992; McIntyre et al., 2007). Similar to non-urbanized semi-arid catchments, runoff depths and runoff ratios increased with $P_{\text {depth }}$ and percent impervious cover, and decreased with catchment size (Goodrich et al., 1997; Murphey et al., 1977; Stone et al., 2008); however, rainfall and land cover could at best explain $50 \%$ of the variance in runoff depths and runoff ratios.

Our data builds upon early urban runoff studies (for example: Arnold and Gibbons, 1996; Paul and Meyer, 2001; Schueler, 1994) by showing that, consistent with results by Ogden et al. (2011), the effects of land cover on runoff depths and runoff ratios vary primarily with the magnitude of rainfall. For example, when rainfall events are large $\left(P_{\text {depth }}>35.4 \mathrm{~mm}\right)$, runoff depths vary in response to (1) the efficiency of runoff mobilization, (2) reductions of streamflow losses to infiltration due to higher catchment percent impervious cover and impervious stream channel density, and (3) shorter hydrologic flow paths, as would be expected as catchment size decreases (Fig. 5a). At mid-range $P_{\text {depth }}(10.8-$ $35.4 \mathrm{~mm}$ ) percent impervious cover explained only $50 \%$ of the runoff depth variance indicating that factors other than land cover, such as the spatial distribution of rainfall, may impart additional controls on urban runoff quantity. At less than average $P_{\text {depth }}$ $(<10.8 \mathrm{~mm})$, runoff depth and runoff ratios increased as road density decreased. This finding is counterintuitive if we consider that street conveyance of overland flow forms part of Tucson's stormwater drainage system (http://rfcd.pima.gov/projects/missionview/), and is therefore likely to increase above ground connectivity between impervious catchment patches. However, these data suggest that when $P_{\text {depth }}$ is small: (1) the contributing areas to runoff are small and are likely located adjacent to the stormwater drainage system or the catchment outlet and (2) a greater proportion of rainfall partitions into overland flow losses to infiltration and/or transient storage.

In contrast to a large body of literature (for example: EPA, 1997; Walsh et al., 2005b), the times to peak discharge we report (0.1$2.1 \mathrm{~h}$ ) are not shorter than in non-urbanized semi-arid catchments (0.1-1.6 $\mathrm{h}$ as reported by Gallo, 2011; Morin et al., 2006). Our data 
Table 5

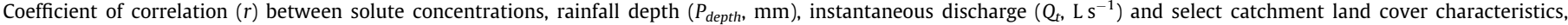
including the stormwater drainage system (stormwater system). Only significant $(p<0.05)$ correlations are shown.

\begin{tabular}{|c|c|c|c|c|c|c|c|c|c|c|c|c|}
\hline \multirow[t]{2}{*}{ Solute } & \multirow{2}{*}{$\begin{array}{l}P_{\text {depth }}{ }^{\mathrm{a}} \\
(\mathrm{mm})\end{array}$} & \multirow{2}{*}{$\begin{array}{l}Q_{t}^{a} \\
\left(\mathrm{Ls}^{-1}\right)\end{array}$} & \multirow{2}{*}{$\begin{array}{l}\text { Runoff } \\
\text { ratio }^{a}\end{array}$} & \multirow{2}{*}{$\begin{array}{l}\text { Impervious } \\
\text { cover }(\%)^{\mathrm{a}}\end{array}$} & \multirow{2}{*}{$\begin{array}{l}\text { Catchment size } \\
\left(\mathrm{km}^{2}\right)^{\mathrm{b}}\end{array}$} & \multicolumn{3}{|c|}{ Percent land cover } & \multicolumn{4}{|c|}{ Densities $\left(\mathrm{km} \mathrm{km}^{-2}\right)$} \\
\hline & & & & & & $\begin{array}{l}\text { Low } \\
\text { density }^{b}\end{array}$ & $\begin{array}{l}\text { Medium } \\
\text { density }^{\mathrm{b}}\end{array}$ & Open $^{\mathrm{b}}$ & Road $^{\text {b }}$ & $\begin{array}{l}\text { Stormwater } \\
\text { system }^{b}\end{array}$ & $\begin{array}{l}\text { Pervious } \\
\text { channel }^{\text {b }}\end{array}$ & $\begin{array}{l}\text { Impervious } \\
\text { channel }^{\mathrm{b}}\end{array}$ \\
\hline $\mathrm{Cl}$ & -0.43 & -0.33 & 1 & 0.27 & 1 & 1 & -0.30 & -0.19 & -0.41 & 1 & -0.12 & 1 \\
\hline $\mathrm{NO}_{2}$ & 1 & 1 & 0.14 & 0.21 & I & 1 & -0.12 & 1 & -0.21 & i & -0.15 & 0.12 \\
\hline $\mathrm{NO}_{3}$ & 0.16 & 0.34 & 0.22 & 1 & I & i & 1 & I & 1 & i & 1 & 1 \\
\hline $\mathrm{NH}_{4}$ & -0.37 & -0.27 & -0.15 & 1 & -0.15 & 1 & 1 & -0.30 & -0.24 & -0.16 & -0.13 & 1 \\
\hline DON & -0.59 & -0.24 & 1 & 1 & 1 & 0.28 & -0.17 & -0.27 & -0.29 & -0.17 & 1 & -0.21 \\
\hline DOC & -0.59 & -0.48 & -0.30 & -0.15 & 0.12 & 0.36 & -0.16 & -0.30 & -0.32 & -0.23 & 1 & -0.31 \\
\hline SRP & 1 & 0.32 & 0.28 & 0.33 & 1 & -0.15 & -0.19 & 1 & 1 & 0.24 & 1 & 0.31 \\
\hline $\mathrm{SO}_{4}$ & -0.52 & -0.30 & -0.17 & 1 & 1 & 0.30 & -0.32 & -0.25 & -0.40 & 1 & 1 & -0.12 \\
\hline E. coli & 1 & 1 & 1 & 1 & I & 1 & 1 & 0.33 & 1 & 0.33 & 1 & 1 \\
\hline $\mathrm{Ca}$ & 1 & -0.31 & 1 & 0.15 & 1 & 1 & 1 & 1 & 1 & 1 & 1 & 1 \\
\hline $\mathrm{K}$ & -0.20 & -0.27 & 1 & 1 & 1 & 1 & 1 & 1 & I & -0.20 & 1 & 1 \\
\hline $\mathrm{Mg}$ & -0.32 & -0.29 & i & 1 & -0.17 & i & i & -0.22 & I & 1 & 1 & i \\
\hline $\mathrm{Na}$ & -0.26 & -0.35 & 1 & 0.29 & 1 & 1 & -0.25 & 1 & -0.27 & 1 & 1 & 0.17 \\
\hline $\mathrm{Al}$ & 1 & 1 & i & 1 & 1 & i & 0.22 & I & 1 & -0.17 & 1 & 1 \\
\hline As & 1 & 1 & 1 & 1 & 1 & -0.16 & 1 & 0.15 & I & 1 & 1 & 1 \\
\hline $\mathrm{Cd}$ & -0.37 & -0.47 & -0.19 & 0.26 & -0.30 & 1 & 1 & -0.3 & -0.24 & 1 & -0.26 & 1 \\
\hline Co & -0.41 & 1 & 1 & 1 & -0.20 & 1 & 0.16 & -0.2 & 1 & -0.18 & -0.17 & 1 \\
\hline $\mathrm{Cu}$ & -0.54 & -0.32 & 1 & 0.28 & -0.19 & 1 & -0.25 & -0.29 & -0.41 & 1 & -0.16 & 1 \\
\hline $\mathrm{Fe}$ & -0.22 & 1 & 1 & 1 & -0.15 & 1 & 1 & 1 & 1 & 1 & 1 & 1 \\
\hline $\mathrm{Hg}$ & -0.73 & i & i & 1 & 1 & 1 & I & I & I & i & i & i \\
\hline $\mathrm{Ni}$ & 1 & -0.23 & I & 1 & I & 1 & i & I & i & I & i & I \\
\hline $\mathrm{Pb}$ & 0.19 & -0.24 & -0.27 & 1 & 1 & 1 & 0.17 & 1 & 1 & -0.17 & -0.15 & 1 \\
\hline V & -0.43 & -0.31 & 1 & 0.17 & -0.18 & 1 & 1 & -0.20 & -0.20 & 1 & -0.21 & 1 \\
\hline $\mathrm{Zn}$ & -0.52 & -0.46 & 1 & 0.3 & -0.24 & 1 & -0.20 & -0.27 & -0.34 & i & -0.19 & i \\
\hline
\end{tabular}

a Indicate log-log regressions

b Indicate linear regressions.

Table 6

Vector values and factor values for rainfall depth, instantaneous discharge $\left(Q_{t}\right)$, runoff ratio and land cover characteristics for the first four rotated factors of the factor analysis on solute concentrations correlations $(n=25)$. The variables that most heavily weight into each factor are noted in bold with a *.

\begin{tabular}{|c|c|c|c|c|}
\hline & $\begin{array}{l}\text { Factor } \\
1\end{array}$ & $\begin{array}{l}\text { Factor } \\
2\end{array}$ & $\begin{array}{l}\text { Factor } \\
3\end{array}$ & $\begin{array}{l}\text { Factor } \\
4\end{array}$ \\
\hline Vector variance & 5.90 & 3.70 & 3.40 & 2.20 \\
\hline Vector variance (\%) & 36.86 & 23.10 & 21.27 & 13.77 \\
\hline Cumulative variance (\%) & 36.86 & 59.96 & 81.23 & 95.00 \\
\hline Rainfall depth & 0.66 & -0.09 & 0.14 & 0.56 \\
\hline$Q_{t}$ & 0.41 & 0.19 & 0.25 & 0.80 \\
\hline Runoff ratio & -0.09 & -0.06 & 0.38 & $0.87^{*}$ \\
\hline Catchment size & 0.07 & $0.94^{*}$ & -0.02 & 0.17 \\
\hline Percent impervious cover & -0.50 & -0.48 & $0.69^{*}$ & 0.19 \\
\hline \multicolumn{5}{|l|}{ Land cover } \\
\hline Low density & -0.59 & $0.68^{*}$ & -0.40 & -0.15 \\
\hline Medium density & $0.85^{*}$ & -0.34 & -0.39 & -0.07 \\
\hline High density & $0.94^{*}$ & -0.04 & 0.07 & 0.17 \\
\hline Commercial & -0.81 & -0.23 & $0.51^{*}$ & 0.13 \\
\hline Open space & 0.58 & 0.23 & 0.66 & 0.37 \\
\hline Landscape evenness & $0.92^{*}$ & 0.16 & 0.23 & 0.22 \\
\hline Catchment slope & -0.60 & $0.73^{*}$ & -0.31 & -0.13 \\
\hline Road density & $0.97^{*}$ & -0.17 & -0.01 & 0.08 \\
\hline $\begin{array}{l}\text { Stormwater drainage system } \\
\text { density }\end{array}$ & 0.03 & 0.12 & $0.94^{*}$ & 0.29 \\
\hline Pervious channel density & 0.03 & $0.96^{*}$ & 0.07 & 0.01 \\
\hline Impervious channel density & 0.03 & -0.46 & $0.84^{*}$ & 0.29 \\
\hline
\end{tabular}

indicate that the flashiness of monsoonal runoff does not vary in response to urbanization, suggesting that despite the characteristics of urban development, the major runoff contributing areas are those in close proximity to the stormwater drainage system and the catchment outlet.
The runoff durations for the four most impervious catchments (0.9-8.9 $\mathrm{h}$ ) are longer than those observed in semi-arid non-urbanized catchments of similar size (0.6-2.5 h, Stone et al., 2008). Since time to peak discharge remains invariant with respect to nonurbanized catchments, significantly longer urban runoff duration is likely due to longer streamflow recession, which given the absence of baseflow may result from changes in overland flow paths due to urbanization. Impervious cover and a higher density of impervious channels may decrease infiltration losses and increase contributing areas to streamflow allowing runoff to travel longer distances and reach the catchment outlet. Larger contributing areas may enhance pervious stream channel wetting and bank storage, which may subsequently drain and prolong streamflow recession. Enhanced wetting of pervious stream channels is of particular importance to runoff quality given that biogeochemical processing within stream channels can alter the magnitude of solute stores available for mobilization during subsequent runoff events. Finally, our findings suggest that urbanization in this semi-arid environment increases the frequency and duration of runoff delivered to areas of focused recharge. However, the fate of this excess urban water and whether it actually enhances recharge in these focused recharge areas remains unclear.

\subsection{Runoff quality responses}

Contrary to our initial expectations, solute concentrations were not consistently related to urban land cover (Fig. 6, Table 4) with runoff quality in the least urbanized catchment (LD) similar to the most urban site (CM). This directly contrasts with literature documenting higher concentrations of solutes in runoff from highly urbanized land covers (Asaf et al., 2004; Choe et al., 2002; Jiries et al., 2001; Lee and Bang, 2000; Lewis and Grimm, 2007; Maestre and Pitt, 2006; Rose, 2002; Tiefenthaler et al., 2008). The 

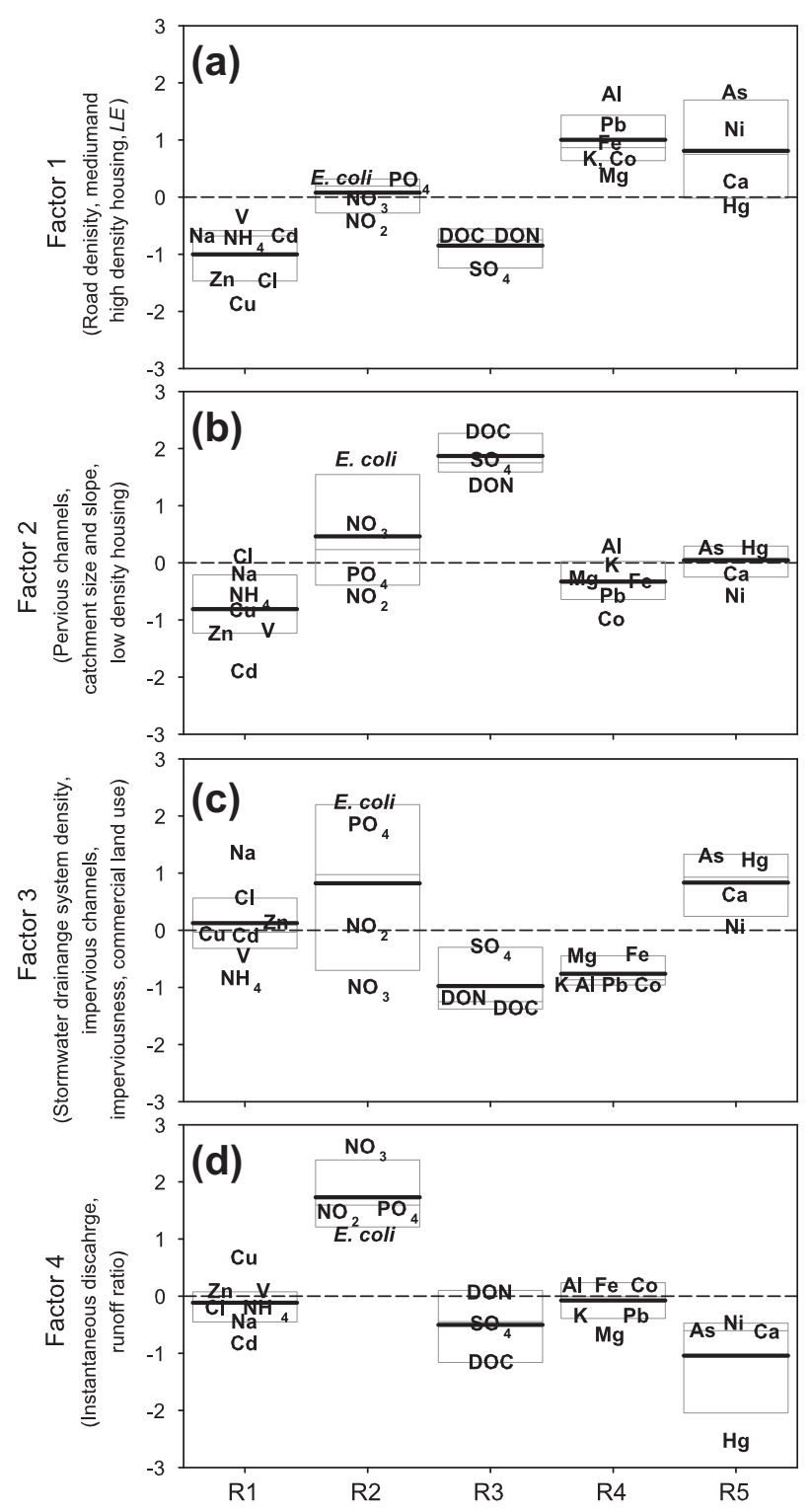

Fig. 7. Box plots showing factor scores of solutes comprising clusters $R 1-R 5$. The thick black line in each cluster box plot denotes the mean factor score, the thin gray line denotes the median and the dashed line across each plot denotes a factor sore of 0 .

observation that some solute concentrations $\left(\mathrm{Cl}, \mathrm{NO}_{3}, E\right.$. coli, $\mathrm{SO}_{4}$, $\mathrm{Ca}, \mathrm{Mg}, \mathrm{Na}$ and $\mathrm{K}$ ) measured in this study were similar to those in protected national parks of the semi-arid Southwest, while other solutes $\left(\mathrm{NO}_{2}, \mathrm{NH}_{4}, \mathrm{SRP}, \mathrm{Al}, \mathrm{As}, \mathrm{Cd}, \mathrm{Co}, \mathrm{Cu}, \mathrm{Fe}, \mathrm{Ni}, \mathrm{Pb}\right.$, and $\mathrm{Zn}$ ) were higher in runoff at our study sites (Brown, 2005) suggests multiple controls on urban runoff quality.

The factor analysis highlights four distinct mechanisms controlling runoff quality: Factor 1 points to variable solute sourcing due to catchment heterogeneity and the degree of above ground connectivity of urban land covers; Factor 2 points to the spatial extent of pervious and biogeochemically active areas, such as pervious stream channels; Factor 3 points to efficient mobilization of storm runoff from the catchment and a reduced biogeochemical potential; while Factor 4 points to solute mobilization (flushing and dilution).

The factor scores and clustering analysis highlight five solute groupings that vary distinctly with Factors 1, 2, 3, and 4. Solutes clustering in $R 1(\mathrm{Cd}, \mathrm{Cu}, \mathrm{Zn}$ and $\mathrm{V})$ are associated with rooftops, as well as industrial, commercial and road land uses (Chebbo and
Gromaire, 2004; Davis et al., 2001; Gromaire et al., 2001; Pitt et al., 1995; Tiefenthaler et al., 2008; Van Metre and Mahler, 2003). We expected the highest concentrations of $R 1$ solutes in catchments with high commercial land uses, road density and imperviousness. However, the highest $R 1$ concentrations occurred in the least and most impervious catchments (LD and CM), which also have the lowest road density. The negative Factor 1 scores of $R 1$ solutes indicate that as the variability of solute sources and above ground catchment connectivity decrease, solute concentrations increase. It is likely that the heavy use of a small number of roads may enhance localized solute sourcing (Lu et al., 2003; Sabin et al., 2005), which when mobilized during runoff, result in high solute concentrations at the least and most impervious catchments. In addition, areas in close proximity to the stormwater drainage network or near the catchment outlet may contribute a large fraction of overland flow and loads of $R 1$ solutes to runoff, explaining why the LD and CM had the highest $R 1$ concentrations despite their low road density.

Solutes associated with biogeochemical processes and redox reactions (Schlesinger, 1997) cluster with $R 2$ and $R 3$ (DOC, $\mathrm{NO}_{3}$, $\mathrm{NO}_{2}$, TDN, SRP and $\mathrm{SO}_{4}$ ). Common sources include organic matter decomposition and soil biogeochemical processing (Austin et al., 2004; Schade and Hobbie, 2005; Sponseller and Fisher, 2006), dry and wet atmospheric deposition (Lohse et al., 2008), the incomplete combustion of fossil fuels (Chen and Mulder, 2007; Zielinska, 2005), fertilizers (Carpenter et al., 1998), and, for SRP and E. coli, particulate transport and agricultural sourcing (Graves et al., 2004; Schoonover and Lockaby, 2006; Servais et al., 2007; Surbeck et al., 2006). Since there are no combined sewers in the Tucson Ba$\mathrm{sin}$, overflow of untreated sewage is not a potential source of $E$. coli (e.g. Arnone and Walling, 2007; Marsalek and Rochfort, 2004).

The positive loading of $R 2$ solutes $\left(\mathrm{NO}_{3}, \mathrm{NO}_{2}, \mathrm{SRP}\right.$ and $E$. coli) onto Factor 4 suggests solute flushing. Given that the Sonoran desert is nitrogen limited (Westerman and Tucker, 1978; Whitford, 2002), we expected to observe nitrogen retention at LD and therefore low $\mathrm{NO}_{3}$ and $\mathrm{NO}_{2}$ runoff concentrations. However, this was not the case and the literature supports a two part explanation for the high $\mathrm{NO}_{3}$ concentrations across sites, which can be extended to all $R 2$ constituents: (1) solutes deposited during dry conditions accumulated within the catchment due to soil water limitations for biogeochemical activity, resulting in mobilization of accumulated solutes during rainfall and subsequent runoff (Lewis and Grimm, 2007; McCrackin et al., 2008) and (2) biogeochemical processes such as mineralization, nitrification and phosphorous retention increase in response to soil wetting, leading to accumulation of solutes in the soil between storm events and which are flushed during subsequent runoff (Austin et al., 2004; Welter et al., 2005). Both of these processes are likely to occur in the uplands and ephemeral stream channels. However, mobilization of solutes from upland soils may not control storm runoff quality if the spatial extent of pervious areas is small, like at CM (9\%). Studies show that ephemeral streams concentrate solutes and runoff in space and time, leading to extended periods of high soil moisture and biogeochemical activity (e.g. McClain et al., 2003; Vidon et al., 2010). Therefore, solute flushing from ephemeral waterways may be of equal or greater importance than solute sourcing form the uplands, particularly as percent impervious cover increases.

Factor scores of $R 3$ solutes (DOC, DON, $\mathrm{SO}_{4}$ ) were negative for Factors 1 and 3 but positive for Factor 2 (Fig. 7, Table 7). The Factor 1 scores suggest that, like $R 1$ solutes, DOC, DON, $\mathrm{SO}_{4}$ are sourced from small contributing areas. The Factor 2 and 3 scores indicate that solute concentrations increased with the extent of pervious area, and decrease with increasing percent impervious cover and runoff mobilization efficiency. Gallo et al. (2012) show early seasonal flushing and mobilization of $R 3$ solutes at these sites. Their findings combined with increasing discharge as the stormwater 
Table 7

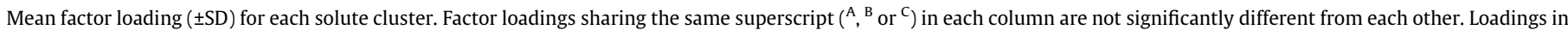
bold and superscripted with a * indicate factors controlling each solute cluster's responses.

\begin{tabular}{|c|c|c|c|c|c|c|}
\hline Cluster & Solutes & $\begin{array}{l}\text { Factor } 1 \text { (road density, } \\
\text { residential housing, } L E \text { ) }\end{array}$ & $\begin{array}{l}\text { Factor } 2 \text { (pervious } \\
\text { channels, catchment } \\
\text { size and slope, \% low } \\
\text { density residential) }\end{array}$ & $\begin{array}{l}\text { Factor } 3 \text { (Percent impervious } \\
\text { cover, \% commercial, stormwater } \\
\text { drainage system and impervious } \\
\text { channel density) }\end{array}$ & $\begin{array}{l}\text { Factor } 4\left(Q_{t} \text { and }\right. \\
\text { runoff ratio })\end{array}$ & Solute behavior \\
\hline$R 1$ & $\begin{array}{l}\mathrm{Cl}, \mathrm{Na}, \\
\mathrm{NH}_{4}, \mathrm{~V}, \\
\mathrm{Cd}, \mathrm{Cu}, \\
\mathrm{Zn}\end{array}$ & $-1.00(0.55)^{\mathrm{C} *}$ & $-0.81(0.68)^{\mathrm{C}}$ & $0.12(0.71)^{\mathrm{AB}}$ & $-0.11(0.45)^{\mathrm{B}}$ & $\begin{array}{l}\text { Metals, cations and } \mathrm{Cl} \text {. } \\
\text { Concentrations vary inversely with } \\
\text { solute sourcing variability }\end{array}$ \\
\hline$R 2$ & $\begin{array}{l}\mathrm{NO}_{2} \\
\mathrm{SRP} \\
\mathrm{NO}_{3} \\
\text { E. coli }\end{array}$ & $0.08(0.34)^{\mathrm{AB}}$ & $0.46(1.04)^{\mathrm{AB}}$ & $0.82(1.53)^{\mathrm{A}}$ & $1.73(0.64)^{A *}$ & $\begin{array}{l}\text { Biogeochemical solutes. } \\
\text { Concentrations vary in response to } \\
\text { the amount of water moving through } \\
\text { the catchment (solute flushing) }\end{array}$ \\
\hline R3 & $\begin{array}{l}\mathrm{DON} \\
\mathrm{SO}_{4} \\
\mathrm{DOC}\end{array}$ & $-0.85(0.35)^{\mathrm{BC} *}$ & $1.87(0.35)^{\mathrm{A} *}$ & $-0.98(0.59)^{\mathrm{AB} *}$ & $-0.5(0.63)^{\mathrm{B}}$ & $\begin{array}{l}\text { Biogeochemical solutes. } \\
\text { Concentrations vary inversely with } \\
\text { solute sourcing variability and } \\
\text { efficiency of runoff mobilization; and } \\
\text { positively with catchment } \\
\text { perviousness }\end{array}$ \\
\hline R4 & $\begin{array}{l}\mathrm{K}, \mathrm{Mg} \\
\mathrm{Fe}, \mathrm{Pb} \\
\mathrm{Co}, \mathrm{Al}\end{array}$ & $1.00(0.5)^{\mathrm{A} *}$ & $-0.33(0.43)^{\mathrm{BC}}$ & $-0.76(0.26)^{\mathrm{B} *}$ & $-0.07(0.35)^{\mathrm{B}}$ & $\begin{array}{l}\text { Base cations and metals. } \\
\text { Concentrations vary in response to } \\
\text { solute sourcing variability and } \\
\text { inversely with the efficiency of } \\
\text { runoff mobilization }\end{array}$ \\
\hline R5 & $\begin{array}{l}\text { Ca, } \mathrm{Ni}, \\
\text { As, } \mathrm{Hg}\end{array}$ & $0.81(0.9)^{\mathrm{A}}$ & $0.04(0.29)^{\mathrm{BC}}$ & $0.84(0.58)^{\mathrm{A} *}$ & $-1.04(0.99)^{\mathrm{B} *}$ & $\begin{array}{l}\text { Base cations and metals. } \\
\text { Concentrations vary with the } \\
\text { efficiency of runoff mobilization and } \\
\text { inversely with the amount of water } \\
\text { moving through the catchment } \\
\text { (solute dilution) }\end{array}$ \\
\hline
\end{tabular}

drainage system density increases (Table 3), and the Factor 2 and 3 scores point to solute dilution during runoff and solute sourcing from pervious areas, such as pervious stream channels and the riparian zone. These patterns are not entirely unexpected given that catchments with extensive percent impervious cover and impervious waterways may have limited stores of DOC, DON and $\mathrm{SO}_{4}$; and given that pervious ephemeral streams are hotspots of biogeochemical activity (McClain et al., 2003), where potentially large solute stores can be mobilized during episodic runoff.

Solutes clustering as $R 4(\mathrm{Al}, \mathrm{Fe}, \mathrm{Pb}, \mathrm{Co}, \mathrm{K}$ and $\mathrm{Mg}$ ) are generally associated with disturbance due to urban development and residential housing construction (Tiefenthaler et al., 2008; Zampella et al., 2007). Positive Factor 1 scores indicate increasing solute concentrations with solute sourcing variability; while negative Factor 3 scores indicate decreasing concentrations as catchment perviousness increased. These solutes had variable responses to event rainfall and $Q_{t}$ (Table 5). It is likely that: (1) variable solute sourcing due to land use heterogeneity and increased above ground catchment connectivity, combined with (2) solute retention in pervious areas, likely due to solute complexation in the soil matrix, explains the invariance of $\mathrm{Fe}, \mathrm{Pb}, \mathrm{Co}$, and $\mathrm{K}$ concentrations across sites, the higher concentrations of $\mathrm{Al}$ and $\mathrm{Mg}$ at $\mathrm{MD}$ and the variable solute concentration responses to rainfall and runoff.

Finally, $R 5$ solutes $\mathrm{Ca}, \mathrm{Ni}$ and As are associated with widespread geologic sourcing in the Tucson Basin as the large extent of calciargid aridisols and calcerous entisols indicates (NRCS-NCOSS, 1995; Robertson, 1989; Tadayon, 1995a, 1995b), whereas Hg is primarily sourced from coal and fossil fuel combustion, waste incineration, long distance atmospheric transport and dry deposition (Ericksen et al., 2005; Fang et al., 2009; Lyman and Gustin, 2008). Widespread sourcing combined with positive Factor 3 and negative Factor 4 scores indicate that land cover has a small effect on runoff concentrations of these solutes. Instead, solute concentrations are controlled by solute mobilization and flushing as the efficiency of runoff routing out of the catchment and magnitude of runoff increased.
Our findings indicate that in this semi-arid environment, runoff quality does not vary exclusively in repose to impervious cover or land use. Rather, our data strongly suggest that the stormwater drainage system characteristics are more important predictors of runoff quality, and impart a strong control on runoff responses as other studies suggest (e.g. Carle et al., 2005; Hatt et al., 2004; Walsh et al., 2005a). Finally, the spatial extent of pervious areas for biogeochemical transformations and solute sourcing and retention emerged as an important factor determining runoff quality in these semi-arid catchments.

\section{Conclusion}

Our findings suggest that rainfall depth, the characteristics of the stormwater drainage system and the variability of solute sourcing due to catchment heterogeneity and above ground connectivity have the most profound effects in controlling runoff responses in our semi-arid study sites. Urbanization in this semiarid environment does not alter runoff depth, water yield, and time to peak discharge of individual runoff events. However, urbanization does substantially increase runoff frequency and duration with potentially important implications for delivery of runoff to areas of focused recharge. The effect of land cover on catchment hydrologic responses varies with the magnitude of rainfall; specifically, increased impervious channelization increases the likelihood of runoff from small rainfall events while rainfall depth and catchment characteristics have a greater control on runoff depths and runoff ratios. Within this hydrologic context, solute chemistry was explained by four mechanisms (1) variable solute sourcing due to land use heterogeneity and above ground patch connectivity, (2) the spatial extent of pervious and biogeochemically active areas, (3) the efficiency of overland flow and runoff routing from the catchment, and (4) solute flushing and dilution. Correlations among some land cover elements, such as imperviousness and impervious channel density, emphasize the effects of landscape 
structure on urban runoff quality and quality. Our analyses highlight the importance of the stormwater drainage system characteristics, specifically the density of pervious stream channels, in controlling urban catchment hydrology and runoff quality in response to monsoonal rainfall, and suggest that active modification of washes may be an effective urban stormwater management strategy. Finally, we suggest that storm runoff monitoring programs should be designed around the characteristics of the drainage system rather than focused on specific land uses.

\section{Acknowledgments}

This study was supported by the Arizona's Technology and Research Initiative Fund (TRIF), the USDA-ARS Water Management and Conservation National Program \# 211, the USDA Ecohydrology Fellowship Program, the University of Arizona's Graduate College Diversity Fellowship program, a Water Sustainability Program Graduate Study Fellowship, the Sustainability of Semi-Arid Hydrology and Riparian Areas (SAHRA) program, and National Science Foundation (NSF) DEB 0918373, 1063362. Dr. Kathleen Lohse, now at Idaho State University, was supported by the National Science Foundation under Award Number EPS-0814387. We would like to thank Dr. Jennifer McIntosh and Dr. Thomas Meixner for their technical support, and Margaret Snyder, Navid Dejwakh, Shane Clark, Mark Carlson, Daniel Wisheropp, Claressa Martinez and the Rainlog.org citizen scientists.

\section{References}

Arizona Game and Fish Department, 2006. Arizona's Comprehensive Wildlife Conservation Strategy: 2005-2015. <www.azgfd.gov/pdfs/w_c/cwcs/ downloads/CWCS_Final_May2006.pdf>.

Arnold, C.L., Gibbons, C.J., 1996. Impervious surface coverage - the emergence of a key environmental indicator. J. Am. Plan. Assoc. 62 (2), 243-258. http:// dx.doi.org/10.1080/01944369608975688.

Arnone, R.D., Walling, J.P., 2007. Waterborne pathogens in urban watersheds. J. Water Health 5 (1), 149-162.

Asaf, L., Nativ, R., Shain, D., Hassan, M., Geyer, S., 2004. Controls on the chemical and isotopic compositions of urban stormwater in a semiarid zone. J. Hydrol. 294 (4), 270-293. http://dx.doi.org/10.1016/j.jhydrol.2004.02.010.

ASCE, 1996. Hydrology Handbook. Manuals and Reports on Engineering Practice. American Society of Civil Engineers, New York, 784pp.

Athayde, D.A., Shelley, P.E., Dricoll, E.D., Gaboury, D., Boyd, G.B., 1983. Results of the Nationwide Urban Runoff Program. W.P.D. Environmental Protection Agency. Water Planning Division, U.S. Environmental Protection Agency: U.S. G.P.O WH-554.

Austin, A.T., Yahdjian, L., Stark, J.M., Belnap, J., Porporato, A., Norton, U., Ravetta, D.A., Schaeffer, S.M., 2004. Water pulses and biogeochemical cycles in arid and semiarid ecosystems. Oecologia 141 (2), 221-235.

Baillie, M.N., Hogan, J.F., Ekwurzel, B., Wahi, A.K., Eastoe, C.J., 2007. Quantifying water sources to a semiarid riparian ecosystem, San Pedro river, Arizona. J. Geophys. Res. - Biogeosci. 112(G3), G03S02. http://dx.doi.org/10.1029/ 2006JG000263.

Berling-Wolff, S., Wu, J., 2004. Modeling urban landscape dynamics: a case study in Phoenix, USA. Urban Ecosyst. 7 (3), 215-240. http://dx.doi.org/10.1023/ B:UECO.0000044037.23965.45.

Brown, J.G., 2005. Water-Quality Data for Selected National Park Units, Southern and Central Arizona and West-Central New Mexico, Water Years 2003 an 2004. United States Geological Survey and The National Park Service. Open-File Report 2005-1291. <http://pubs.usgs.gov/of/2005/1291/>

Brown, L.R., Cuffney, T.F., Coles, J.F., Fitzpatrick, F., McMahon, G., Steuer, J., Bell, A.H May, J.T., 2009. Urban streams across the USA: lessons learned from studies in 9 metropolitan areas. J. North Am. Benthol. Soc. 28 (4), 1051-1069.

Carle, M.V., Halpin, P.N., Stow, C.A., 2005. Patterns of watershed urbanization and impacts on water quality. J. Am. Water Resour. Assoc. 41 (3), 693-708.

Carlson, M.A., Lohse, K.A., McIntosh, J.C., McLain, J.E.T., 2011. Impacts of urbanization on groundwater quality and recharge in a semi-arid alluvial basin. J. Hydrol. 409, 196-211. http://dx.doi.org/10.1016/j.jhydrol.2011.08.020.

Carpenter, S.R., Caraco, N.F., Correll, D.L., Howarth, R.W., Sharpley, A.N., Smith, V.H., 1998. Nonpoint pollution of surface waters with phosphorus and nitrogen. Ecol. Appl. 8 (3), 559-568

Chebbo, G., Gromaire, M.C., 2004. The experimental urban catchment 'Le Marais' in Paris: what lessons can be learned from it? J. Hydrol. 299 (3-4), 312-323.

Chen, X.Y., Mulder, J., 2007. Atmospheric deposition of nitrogen at five subtropical forested sites in South China. Sci. Total Environ. 378 (3), 317-330.

Choe, J.S., Bang, K.W., Lee, J.H., 2002. Characterization of surface runoff in urban areas. Water Sci. Technol. 45 (9), 249-254.
Chralowicz, D., Dominguez, A., Goff, T., Mascali, M., Taylor, E., 2001. Infiltration of Urban Stormwater Runoff to Recharge Groundwater Used for Drinking Water: A Study of the San Fernando Valley, California. University of California, Santa Barbara, 104pp.

Coes, A.L., Pool, D.R., 2007. Ephemeral-stream channel and basin-floor infiltration and recharge in the Sierra Vista subwatershed of the upper San Pedro basin, southeastern Arizona. In: Stonestrom, D.A., Jim, Constantz, Ferre, T.P.A., Leake, S.A. (Eds.), Ground-water Recharge in the Arid and semiarid Southwestern United States. Unites States Geological Survey. Ground-water Resources, Program, Reston, VA, pp. 253-311. http://pubs.usgs.gov/pp/pp1703/j.

Comrie, A.C., Broyles, B., 2002. Variability and spatial modeling of fine-scale precipitation data for the Sonoran Desert of south-west Arizona. J. Arid Environ. 50 (4), 573-592.

Crowley, J., O'Brien, J., Tulloch, C., Higgins, D., Haake, K., Adams, L., Silva, M., Norman, C., 2005. Urban Water Management Plan. Santa Clara Water District, Santa Clara, California.

Davis, A.P., Shokouhian, M., Ni, S.B., 2001. Loading estimates of lead, copper, cadmium, and zinc in urban runoff from specific sources. Chemosphere 44 (5), 997-1009.

Decook, K.J., Foster, K.E., 1984. Systems for rainfall and runoff use, Tucson, Arizona. Water Resour. Bull. 20 (6), 883-888.

DeCoster, J., 1998. Overview of Factor Analysis. <http://www.stat-help.com/ notes.html> (accessed 23.01.11).

Eastoe, C.J., Gu, A., Long, A., 2004. The origins, ages and flow paths of gorundwater in Tucson Basin: results of a study of multiple isotope systems. In: Hogan, J.F., Phillips, F.M., Scanlon, B.R. (Eds.), Groundwater Recharge in a Desert Environment: The Southwestern United States. American Geophysical Union, Washington, DC

EPA, U.S., 1997. Urbanization and Streams: Studies of Hydrologic Impacts. U.S. Environmental Protection Agency, Office of Water, 841-R-97-009.

EPA, U.S., 2002. Method 1604: Total Coliforms and Escherichia coli in Water by Membrane Filtration Using a Simultaneous Detection Technique (MI Medium). Environmental Protection Agency, Washington, DC, Publication 821-R-02-024. <http://www.epa.gov/nerlcwww/1604sp02.pdf>.

Ericksen, J.A., Gustin, M.S., Lindberg, S.E., Olund, S.D., Krabbenhoft, D.P., 2005. Assessing the potential for re-emission of mercury deposited in precipitation from arid soils using a stable isotope. Environ. Sci. Technol. 39 (20), 8001-8007.

Fang, G.C., Wu, Y.S., Chang, T.H., 2009. Comparison of atmospheric mercury (Hg) among Korea, Japan, China and Taiwan during 2000-2008. J. Hazard. Mater. 162 (2-3), 607-615

Gallo, E.L., 2011. Patterns and Controls of Urban Runoff Quantity and Quality in Catchments of the Semi-arid Southwest. Doctoral Dissertation Thesis. University of Arizona, Tucson, 240pp.

Gallo, E.L., Brooks, P., Lohse, K.A., McLain, J.E., 2012. Temporal patterns and controls on runoff magnitude and solution chemistry of urban catchments in the semiarid southwest. Hydrol. Process.. http://dx.doi.org/10.1002/hyp. 9199.

Garcia, M., Peters-Lidard, C.D., Goodrich, D.C., 2008. Spatial interpolation of precipitation in a dense gauge network for monsoon storm events in the southwestern United States. Water Resour. Res. 44, W05S13(5), 14. http:// dx.doi.org/10.1029/2006WR005788.

Gelt, J., Henderson, J., Seasholes, K., Tellman, B., Woodard, G., Carpenter, K., Hudson, C., Sherif, S., 1999. Water in the Tucson Area: Seeking Sustainability, a Status Report. Water Resources and Research Center, The University of Arizona.

Gibson, J.J., Sadek, M.A., Stone, D.J.M., Hughes, C.E., Hankin, S., Cendon, D.I., Hollins, S.E., 2008. Evaporative isotope enrichment as a constraint on reach water balance along a dryland river. Isot. Environ. Health Stud. 44 (1), 83-98.

Gochis, D.J., Brito-Castillo, L., Shuttleworth, W.J., 2006. Hydroclimatology of the North American Monsoon region in northwest Mexico. J. Hydrol. 316 (1-4), 5370, http://dx.doi.org/10.1016/j.jhydrol.2005.04.021

Goodrich, D.C., Lane, L.J., Shillito, R.M., Miller, S.N., Syed, K.H., Woolhiser, D.A., 1997. Linearity of basin response as a function of scale in a semiarid watershed. Water Resour. Res. 33 (12), 2951-2965.

Goodrich, D.C., Unkrich, C.L., Keefer, T.O., Nichols, M.H., Stone, J.J., Levick, L.R., Scott, R.L., 2008. Event to multidecadal persistence in rainfall and runoff in southeast Arizona. Water Resour. Res. 44, W05S14(5). http://dx.doi.org/10.1029/ 2007WR006222.

Goodrich, D.C., Williams, D.G., Unkrich, C.L., Hogan, J.F., Scott, R.L., Hultine, K., Pool, D., Coes, A.L., Miller, S., 2004. Comparison of methods to estimate Ephemeral Channel Recharge, Walnut Gulch, San Pedro River Basin, Arizona. In: Hogan, J.F., Phillips, F.M., Scanlon, B.R. (Eds.), Groundwater Recharge in a Desert Environment: The Southwestern United States. American Geophysical Union, Washington, DC

Graves, G.A., Wan, Y.S., Fike, D.L., 2004. Water quality characteristics of storm water from major land uses in South Florida. J. Am. Water Resour. Assoc. 40 (6), 14051419.

Gromaire, M.C., Garnaud, S., Saad, M., Chebbo, G., 2001. Contribution of different sources to the pollution of wet weather flows in combined sewers. Water Res. 35 (2), 521-533.

Guido, Z., 2008. Understanding the Southwestern Monsoon. Southwest Climate Change Network. <http://www.southwestclimatechange.org/feature-articles/ southwest-monsoon>.

Hatt, B.E., Fletcher, T.D., Walsh, C.J., Taylor, S.L., 2004. The influence of urban density and drainage infrastructure on the concentrations and loads of pollutants in small streams. Environ. Manage. 34, 112-124.

Hayter, A.J., 1984. A proof of the conjecture that the Tukey-Kramer multiple comparisons procedure is conservative. Ann. Stat. 12 (1), 61-75. 
Hoffmann, J.P., Blasch, K.W., Pool, D.R., Bailey, M.A., Callegary, J.B., 2007. Estimated Infiltration, Percolation, and Recharge Rates at the Rillito Creek Focused Recharge Investigation Site, Pima County, Arizona. 1703-H, U.S. Geological Survey. <http://pubs.usgs.gov/pp/pp1703/h/>.

Houser, P., Goodrich, D., Syed, K., U.S.D.A., A.R.S., 2000. Runoff, precipitation and soil moisture at Walnut Gulch. In: Grayson, R., Blöschl, G.N. (Eds.), Spatial Patterns in Catchment Hydrology: Observations and Modelling. Cambridge University Press, Cambridge, UK, pp. 125-157. <http://hdl.handle.net/10113/47530>.

Ishaq, A.M., 1992. Surface and subsurface drainage of metropolitan city in arid zone. J. Irrig. Drain. Eng. - ASCE 118 (1), 19-35.

Ishaq, A.M., Alassar, R.S., 1999. Characterizing urban storm runoff quality in Dhahran City in Saudi Arabia. Water Int. 24 (1), 53-58.

Jiries, A.G., Hussein, H.H., Halaseh, Z., 2001. The quality of water and sediments of street runoff in Amman, Jordan. Hydrol. Process. 15 (5), 815-824.

Kaiser, H.F., 1958. The varimax criterion for analytic rotation in factor-analysis. Psychometrika 23 (3), 187-200.

Lee, J.H., Bang, K.W., 2000. Characterization of urban stormwater runoff. Water Res. 34 (6), 1773-1780.

Lehman, A., O'Rouke, N., Hatcher, L., Stepanski, E.J., 2005. JMP for Basic Univariate and Multivariate Statistics a Step-By-Step Guide. SAS Press, Cary, NC.

Lewis, D.B., Grimm, N.B., 2007. Hierarchical regulation of nitrogen export from urban catchments: interactions of storms and landscapes. Ecol. Appl. 17 (8), 2347-2364.

Lohse, K.A., Hope, D., Sponseller, R., Allen, J.O., Grimm, N.B., 2008. Atmospheric deposition of carbon and nutrients across an and metropolitan area. Sci. Total Environ. 402 (1), 95-105.

Loik, M.E., Breshears, D.D., Lauenroth, W.K., Belnap, J., 2004. A multi-scale perspective of water pulses in dryland ecosystems: climatology and ecohydrology of the western USA. Oecologia 141 (2), 269-281. http:// dx.doi.org/10.1007/s00442-004-1570-y.

Lu, R., Turco, R.P., Stolzenbach, K., Friedlander, S.K., Xiong, C., Schiff, K., Tiefenthaler, L., Wang, G.Y., 2003. Dry deposition of airborne trace metals on the Los Angeles Basin and adjacent coastal waters. J. Geophys. Res. - Atmos. 108(D2)

Ludington, S., Moring, B.C., Miller, R.J., Stone, P.A., Bookstrom, A.A., Bedford, D.R., Evans, J.G., Haxel, G.A., Nutt, C.J., Flyn, K.S., Hopkins, M.J., 2007. Preliminary integrated geologic map databases for the United States Western States: California, Nevada, Arizona, Washington, Oregon, Idaho, and Utah, Version 1.3. United States Geological Survey. Open-File Report 2005-1305. <http:// pubs.usgs.gov/of/2005/1305/index.htm>.

Lyman, S.N., Gustin, M.S., 2008. Speciation of atmospheric mercury at two sites in northern Nevada, USA. Atmos. Environ. 42 (5), 927-939.

Maestre, A., Pitt, R., 2006. Identification of significant factors affecting stormwater quality using the NSQD. In: James, W., Irvine, K.N., McBean, E.A., Pitt, R.E. (Eds.), Stormwater and Urban Water Systems Modeling Proceedings, Monograph 14. Guelph, Ontario, pp. 287-326.

Marsalek, J., Rochfort, Q., 2004. Urban wet-weather flows: sources of fecal contamination impacting on recreational waters and threatening drinkingwater sources. J. Toxicol. Environ. Health A - Curr. Issues 67 (20-22), 17651777.

McClain, M.E., Boyer, E.W., Dent, C.L., Gergel, S.E., Grimm, N.B., Groffman, P.M., Hart, S.C., Judson, W.H., Johnston, C.A., Mayorga, E., McDowell, W.H., Pinay, G., 2003. Biogeochemical hot spots and hot moments at the interface of terrestrial and aquatic ecosystems. Ecosystems 6 (4), 301-312, http://www.jstor.org/stable/ 4095691.

McCrackin, M.L., Harms, T.K., Grimm, N.B., Hall, S.J., Kaye, J.P., 2008. Responses of soil microorganisms to resource availability in urban, desert soils. Biogeochemistry 87 (2), 143-155.

McIntyre, N., Al-Qurashi, A., Wheater, H., 2007. Regression analysis of rainfallrunoff data from an arid catchment in Oman. Hydrol. Sci. J. - J. Sci. Hydrol. 52 (6), 1103-1118.

Meierdiercks, K.L., Smith, J.A., Baeck, M.L., Miller, A.J., 2010. Analyses of urban drainage network structure and its impact on hydrologic response. JAWRA - J. Am. Water Resour. Assoc. 46 (5), 932-943. http://dx.doi.org/10.1111/j.17521688.2010.00465.x.

Mendez, A., Goodrich, D.C., Osborn, H.B., 2003. Rainfall point intensities in an air mass thunderstorm environment: Walnut Gulch, Arizona. JAWRA - J. Am. Water Resour. Assoc. 39 (3), 611-621.

Morin, E., Goodrich, D.C., Maddox, R.A., Gao, X., Gupta, H.V., Sorooshian, S., 2006. Spatial patterns in thunderstorm rainfall events and their coupling with watershed hydrological response. Adv. Water Resour. 29 (6), 843-860, http:// dx.doi.org/10.1016/j.advwatres.2005.07.014.

Morin, E., Krajewski, W.F., Goodrich, D.C., Gao, X., Sorooshian, S., 2003. Estimating rainfall intensities from weather radar data: the scale-dependency problem. J. Hydrometeorol. 4 (5), 782-797, http://dx.doi.org/10.1175/1525-7541(2003) 004<0782:ERIFWR>2.0.CO;2.

Murphey, J.B., Wallace, D.E., Lane, L.J., 1977. Geomorphic parameters predict hydrograph characteristics in the Southwest. JAWRA - J. Am. Water Resour. Assoc. 13 (1), 25-37. http://dx.doi.org/10.1111/j.1752-1688.1977.tb01987.x.

Natural Resources Conservation Service, S.S.S., United States Department of Agriculture, 2008. Soil Survey Geographic (SSURGO) Database for Tucson-Avra Valley and Pima County, Arizona. <http://soildatamart.nrcs.usda.gov> (accessed 09.08.08).

Norman, L.M., Feller, M., Guertin, D.P., 2009. Forecasting urban growth across the United States-Mexico border. Comput. Environ. Urban Syst. 33 (2), 150-159.

NRCS-NCOSS, 1995. State Soil Survey Geographic Data Base U.S. Coverage by States Including Puerto Rico, Excludes Alaska. U.S. Dept. of Agriculture, Natural
Resources Conservation Service. National Cooperative Soil Survey, [Fort Worth, Tex.].

Ogden, F.L., Raj Pradhan, N., Downer, C.W., Zahner, J.A., 2011. Relative importance of impervious area, drainage density, width function, and subsurface storm drainage on flood runoff from an urbanized catchment. Water Resour. Res. 47 (12), W12503. http://dx.doi.org/10.1029/2011WR010550.

Osborn, H.B., Lane, L., 1969. Precipitation-runoff relations for very small semiarid rangeland watersheds. Water Resour. Res. 5(2), 419.

Paul, M.J., Meyer, J.L., 2001. Streams in the urban landscape. Annu. Rev. Ecol. Syst. $32,333-365$

Pielou, E.C., 1966. The measurement of diversity in different types of biological collections. J. Theor. Biol. 13, 131-144. http://dx.doi.org/10.1016/00225193(66)90013-0.

Pitt, R., Field, R., Lalor, M., Brown, M., 1995. Urban stormwater toxic pollutants assessment, sources, and treatability. Water Environ. Res. 67 (3), 260-275.

Pitt, R.E., Maestre, A., Hyche, H., Togawa, N., 2008. The updated stormwater quality database (NSQD), version 3. Proc. Water Environ. Fed. 2008, 1007-1026.

Resnick, S.D., DeCook, K.J., Phillips, R.A., 1983. Hydrological and Environmental Controls on Water Management in Semiarid Urban Areas: Phase II. University of Arizona - Water Resources Research Center and Dept. of Civil Engineering, Tucson, Arizona.

Robertson, F.N., 1989. Arsenic in ground-water under oxidizing conditions, southwest United States. Environ. Geochem. Health 11 (3-4), 171-185.

Rose, S., 2002. Comparative major ion geochemistry of Piedmont streams in the Atlanta, Georgia region: possible effects of urbanization. Environ. Geol. 42 (1) $102-113$.

Rosner, B., 1995. Fundamentals of Biostatistics. Duxburry Press, A Wadsworth Publishing Company, Belmont, CA, 682pp.

Sabin, L.D., Lim, J.H., Stolzenbach, K.D., Schiff, K.C., 2005. Contribution of trace metals from atmospheric deposition to stormwater runoff in a small impervious urban catchment. Water Res. 39 (16), 3929-3937.

Sall, J., Creighton, L., Lehman, A., 2007. JMP Start Statistics a Guide to Statistics and Data Analysis Using JMP. SAS Institute, Cary, NC.

Schade, J.D., Hobbie, S.E., 2005. Spatial and temporal variation in islands of fertility in the Sonoran Desert. Biogeochemistry 73 (3), 541-553. http://dx.doi.org/ 10.1007/s10533-004-1718-1.

Schlesinger, W.H., 1997. Biogeochemistry: An Analysis of Global Change. Academic Press, San Diego, California.

Schoonover, J.E., Lockaby, B.G., 2006. Land cover impacts on stream nutrients and fecal coliform in the lower Piedmont of West Georgia. J. Hydrol. 331 (3-4), 371 382.

Schueler, T.R., 1994. The importance of imperviousness. Watershed Protect. Tech. 1 (3), 100-111.

Serrat-Capdevila, A., Valdes, J.B., Perez, J.G., Baird, K., Mata, L.J., Maddock, T., 2007. Modeling climate change impacts and uncertainty on the hydrology of a riparian system: The San Pedro Basin (Arizona/Sonora). J. Hydrol. 347 (1-2), 4866. http://dx.doi.org/10.1016/j.jhydrol.2007.08.028.

Servais, P., Garcia-Armisen, T., George, I., Billen, G., 2007. Fecal bacteria in the rivers of the Seine drainage network (France): sources, fate and modelling. Sci. Total Environ. 375 (1-3), 152-167.

Shuster, W.D., Bonta, J., Thurston, H., Warnemuende, E., Smith, B.J., 2005. Impacts of impervious surface on watershed hydrology: a review. Urban Water J. 2 (4), 263-275.

Smullen, J.T., Shallcross, A.L., Cave, K.A., 1999. Updating the US nationwide urban runoff quality data base. Water Sci. Technol. 39 (12), 9-16.

Sponseller, R.A., Fisher, S.G., 2006. Drainage size, stream intermittency, and ecosystem function in a Sonoran Desert landscape. Ecosystems 9 (3), 344-356.

Stone, J.J., Nichols, M.H., Goodrich, D.C., Buono, J., 2008. Long-term runoff database, Walnut Gulch Experimental Watershed, Arizona, United States. Water Resour. Res. 44 (5).

Strobl, C. Malley, J, Tutz, G., 2009. An Introduction to Recursive Partitioning: Rationale, Application and Characteristics of Classification and Regression Trees, Bagging and Random Forests. Technical Report Number 55. Department of Statistics, University of Munich. epub.ub.uni-muenchen.de/10589/1/ partitioning.pdf.

Surbeck, C.Q., Jiang, S.C., Ahn, J.H., Grant, S.B., 2006. Flow fingerprinting fecal pollution and suspended solids in stormwater runoff from an urban coasta watershed. Environ. Sci. Technol. 40 (14), 4435-4441.

Syed, K.H., Goodrich, D.C., Myers, D.E., Sorooshian, S., 2003. Spatial characteristics of thunderstorm rainfall fields and their relation to runoff. J. Hydrol. 271 (1-4), 121, http://dx.doi.org/10.1016/S0022-1694(02)00311-6.

Tadayon, S., 1995a. Quality of Surface Water and Ground Water in the Proposed Artificial-Recharge Project Area, Rillito Creek Basin, Tucson, Arizona, 1994. U.S Geological Survey Water-Resources Investigations. Report 95-4270.

Tadayon, S., 1995b. Quality of Water and Chemistry of Bottom Sediment in the Rillito Creek Basin, Tucson, Arizona, 1992-93. U.S. Geological Survey WaterResources Investigations. Report 94-4114

Tan, P.-N., Steinbach, M., Kumar, V., 2005. Cluster analysis: basic concepts and algorithms. In: Introduction to Data Mining. Pearson Addison Wesley, Boston (Chapter 8)

Tiefenthaler, L.L., Stein, E.D., Schiff, K.C., 2008. Watershed and land use-based sources of trace metals in urban storm water. Environ. Toxicol. Chem. 27 (2), 277-287.

Unland, H.E., Houser, P.R., Shuttleworth, W.J., Yang, Z.L., 1996. Surface flux measurement and modeling at a semi-arid Sonoran Desert site. Agric. For. Meteorol. 82 (1-4), 119-153. 
Van Metre, P.C., Mahler, B.J., 2003. The contribution of particles washed from rooftops to contaminant loading to urban streams. Chemosphere 52 (10), 1727 1741.

Vidon, P., Allan, C., Burns, D., Duval, T.P., Gurwick, N., Inamdar, S., Lowrance, R., Okay, J., Scott, D., Sebestyen, S., 2010. Hot spots and hot moments in riparian zones: potential for improved water quality management. J. Am. Water Resour. Assoc. 46 (2), 278-298. http://dx.doi.org/10.1111/j.1752-1688.2010.00420.x.

Walsh, C.J., Fletcher, T.D., Ladson, A.R., 2005a. Stream restoration in urban catchments through redesigning stormwater systems: looking to the catchment to save the stream. J. North Am. Benthol. Soc. 24 (3), 690-705.

Walsh, C.J., Fletcher, T.D., Ladson, A.R., 2009. Retention capacity: a metric to link stream ecology and storm-water management. J. Hydrol. Eng. 14 (4), 399-406. http://dx.doi.org/10.1061/(ASCE)1084-0699(2009) 14:4(399.

Walsh, C.J., Roy, A.H., Feminella, J.W., Cottingham, P.D., Groffman, P.M., Morgan, R.P., 2005b. The urban stream syndrome: current knowledge and the search for a cure. J. North Am. Benthol. Soc. 24 (3), 706-723.

Welter, J.R., Fisher, S.G., Grimm, N.B., 2005. Nitrogen transport and retention in an arid land watershed: influence of storm characteristics on terrestrial-aquatic linkages. Biogeochemistry 76 (3), 421-440.

Weng, Y.C., 2007. Spatiotemporal changes of landscape pattern in response to urbanization. Landsc. Urban Plan. 81 (4), 341-353.

Wenger, S.J., Roy, A.H., Jackson, C.R., Bernhardt, E.S., Carter, T.L., Filoso, S., Gibson, C.A., Hession, W.C., Kaushal, S.S., Marti, E., Meyer, J.L., Palmer, M.A., Paul, M.J., Purcell, A.H., Ramirez, A., Rosemond, A.D., Schofield, K.A., Sudduth, E.B., Walsh, C.J., 2009. Twenty-six key research questions in urban stream ecology: an assessment of the state of the science. J. North Am. Benthol. Soc. 28 (4), 10801098.

Westerman, R.L., Tucker, T.C., 1978. Factors affecting denitrification in a Sonoran Desert soil. Soil Sci. Soc. Am. J. 42 (4), 596-599.

Whitford, W.G., 2002. Ecology of Desert Systems. Academic Press, San Diego.

Wilson, L.G., Matlock, W.G., Jacobs, K.L., 1998. Hydrogeologic uncertainties and policy implications: the Water Consumer Protection Act of Tucson, Arizona, USA. Hydrogeol. J. 6 (1), 3-14. http://dx.doi.org/10.1007/s100400050129.

Zampella, R.A., Procopio, N.A., Lathrop, R.G., Dow, C.L., 2007. Relationship of landuse/land-cover patterns and surface-water quality in the Mullica River basin. J. Am. Water Resour. Assoc. 43 (3), 594-604.

Zhang, H., 2004. Recursive partitioning and tree-based methods. In: Gentle, J.E. Härdle, W., Mori, Y. (Eds.), Handbook of Computational Statistics: Concepts and Methods. Springer, Berlin, New York, pp. 1070. <http://hdl.handle.net/10419/ 22203>.

Zhang, L.Q., Wang, H.Z., 2006. Planning an ecological network of Xiamen Island (China) using landscape metrics and network analysis. Landsc. Urban Plan. 78 (4), 449-456. http://dx.doi.org/10.1016/j.landurbplan.2005.12.004.

Zhang, Y., Wei, H., Nearing, M.A., 2011. Effects of antecedent soil moisture on runoff modeling in small semiarid watersheds of southeastern Arizona. Hydrol. Earth Syst. Sci. Discuss. 8 (3), 6227-6256. http://dx.doi.org/10.5194/hessd-8-62272011.

Zielinska, B., 2005. Atmospheric transformation of diesel emissions. Exp. Toxicol. Pathol. 57 (Suppl. 1), 31-42. 